\title{
A Polyphasic Reassessment of the Genus Paenibacillus, Reclassification of Bacillus lautus (Nakamura 1984) as Paenibacillus lautus comb. nov. and of Bacillus peoriae (Montefusco et al. 1993) as Paenibacillus peoriae comb. nov., and Emended Descriptions of $P$. lautus and of $P$. peoriae
}

\author{
M. HEYNDRICKX, ${ }^{1} \mathrm{~K}$. VANDEMEULEBROECKE, ${ }^{1} \mathrm{P} . \mathrm{SCHELDEMAN},{ }^{1} \mathrm{~K}$. KERSTERS,${ }^{1} \mathrm{P} . \mathrm{DE}$ VOS,${ }^{1 *}$ \\ N. A. LOGAN, ${ }^{2}$ A. M. AZIZ, ${ }^{2}$ N. ALI, ${ }^{3}$ AND R. C. W. BERKELEY ${ }^{3}$ \\ Laboratorium voor Microbiologie, Universiteit Gent, B-9000 Ghent, Belgium, ${ }^{1}$ and Department of Biological Sciences, \\ Glasgow Caledonian University, Glasgow G4 OBA, ${ }^{2}$ and Department of Pathology and Microbiology, \\ School of Medical Sciences, University of Bristol, Bristol BS8 1TD, ${ }^{3}$ United Kingdom
}

\begin{abstract}
Seventy-seven strains representing 10 species in the Paenibacillus polymyxa 16S rRNA group and 3 other species that exhibit phenetic relatedness to members of this group, Bacillus lautus, "Bacillus longisporus," and Bacillus peoriae, were characterized genotypically and phenotypically by performing an amplified ribosomal DNA restriction analysis, a randomly amplified polymorphic DNA analysis, a fatty acid methyl ester analysis, sodium dodecyl sulfate-polyacrylamide gel electrophoresis of whole-cell proteins, pyrolysis mass spectrometry, and API and other routine phenotypic tests. These analyses revealed distinct clusters representing Paenibacillus alvei, Paenibacillus amylolyticus, Paenibacillus azotofixans, Paenibacillus durum, Paenibacillus larvae subsp. larvae, Paenibacillus larvae subsp. pulvifaciens, B. lautus, Paenibacillus macerans, Paenibacillus macquariensis, $\boldsymbol{B}$. peoriae, $P$. polymyxa, and Paenibacillus validus, which confirmed the distinctness of these species, but appreciable within-species heterogeneity was observed in $P$. alvei, B. lautus, $P$. macerans, $P$. polymyxa, and $P$. validus. The type strain of Paenibacillus pabuli did not cluster with other strains of this species, and in several analyses a relationship between strains of $P$. pabuli and " $B$. longisporus" was observed. As the analyses showed that $B$. lautus and $B$. peoriae are closely related to the genus Paenibacillus, these species are reclassified as members of this genus.
\end{abstract}

Despite the comprehensive studies of Smith et al. $(38,39)$ and Gordon et al. (9), identification of Bacillus species remains difficult (if only by reputation) and intimidating for most bacteriologists because of taxonomic and practical problems. In order to alleviate the practical problems, Logan and Berkeley (21) developed an identification scheme in which the API system was used. This scheme has been widely used, but new species have been described since it was developed and the taxonomic problems remain.

The wide range of DNA base compositions of Bacillus strains (32 to $69 \mathrm{~mol} \% \mathrm{G}+\mathrm{C})(3,31,37)$ supports the subdivision of the genus Bacillus into several, more homogeneous genera. The results of analyses of genomic data are now providing a rational basis for subdividing the genus. Comparisons of rRNA sequences of the type strains of many Bacillus species have generated outlines of phylogenetic relationships within the genus $(1,17,34)$ which indicate that four of the eight organisms which Smith et al. (39) placed in their group 2 (sporangia definitely swollen by oval spores), Bacillus polymyxa, Bacillus alvei, Bacillus macerans, and Bacillus pulvifaciens, fall into a phylogenetically distinct cluster, the " $B$. polymyxa group," along with Bacillus larvae and six more recently described species whose spores swell their sporangia, Bacillus macquariensis (23), Bacillus azotofixans (35), Bacillus gordonae (32), and three species comprising strains formerly labelled

${ }^{*}$ Corresponding author. Mailing address: Universiteit Gent, Vakgroep BFM WE10V, Laboratorium voor Microbiologie, K. L. Ledeganckstraat 35, B-9000 Ghent, Belgium. Phone: 32 (0)9 264 5110. Fax: 32 (0)9 264 5346. Electronic mail address: Paul.Devos@rug.ac.be.
Bacillus circulans (namely, Bacillus amylolyticus, Bacillus pabuli, and Bacillus validus) (27). This group of organisms was recently reclassified in the new genus Paenibacillus (2).

The four other organisms that Smith et al. (39) placed in their group 2 were $B$. circulans, Bacillus brevis, Bacillus laterosporus, and Bacillus stearothermophilus. Although phenetically related to the B. polymyxa group, $B$. circulans and Bacillus lautus (the latter was another species established by Nakamura [27] from strains previously labelled $B$. circulans) were, surprisingly, determined by $16 \mathrm{~S}$ rRNA sequence analyses to belong to the main Bacillus rRNA group, which contains the type species, Bacillus subtilis (1). The type strains of B. stearothermophilus and $B$. brevis, together with $B$. laterosporus, were found to belong to other rRNA groups. A further complication is that strains of non-spore-forming, gram-positive genera, such as the genera Enterococcus, Lactobacillus, and Leuconostoc, exhibit higher levels of 16S rRNA sequence similarity to the main $B$. subtilis cluster than members of the B. polymyxa group exhibit (34).

While the distinctness of the phylogenetic clusters described above allows subdivision of the genus Bacillus, the clusters are based for the most part on a single strain of each taxon (1). Such an approach can give anomalous results if the strains included are poor representatives of their taxa and/or are misnamed, and it does not reveal within-strain or within-species variations of rRNA cistrons (4). At present it is still laborious and expensive to obtain complete rRNA sequences of adequate numbers of strains. It is therefore helpful to infer a reliable outline of phylogenetic relationships by using a rapid technique, such as amplified ribosomal DNA (rDNA) restriction analysis (ARDRA) (15), as part of a polyphasic taxonomic 
study. An overview of the applicability of polyphasic taxonomy was published recently by Vandamme et al. (41).

In 1993, in light of developments to that date, the International Committee on Systematic Bacteriology Subcommittee on the Taxonomy of the Genus Bacillus (16) resolved to undertake a collaborative polyphasic taxonomic study of Bacillus species, starting with the species belonging to the B. polymyxa group (rRNA group 3) (1) (i.e., the genus Paenibacillus) (2), in order to examine the taxonomy of these organisms in more detail, to revise the nomenclature of this group, to construct an updated identification scheme, and to establish minimal standards for descriptions of species. In this paper we describe the results of a polyphasic study in which 77 named cultures obtained from public and private collections, including cultures of Paenibacillus alvei, Paenibacillus amylolyticus, Paenibacillus azotofixans, Paenibacillus gordonae (a later subjective synonym of Paenibacillus validus) (14), Paenibacillus larvae (reclassified as a subspecies of $P$. larvae) (13), Paenibacillus macerans, Paenibacillus macquariensis, Paenibacillus pabuli, Paenibacillus polymyxa, Paenibacillus pulvifaciens (reclassified as a subspecies of P. larvae) (13), P. validus, Bacillus peoriae (25), B. lautus, and "Bacillus longisporus," were characterized and analyzed by using the methods described by Heyndrickx et al. (14). The recently reclassified species Paenibacillus durum (formerly Clostridium durum) (5) was included in only the ARDRA portion of this study.

\section{MATERIALS AND METHODS}

Strains, media, and growth conditions. The designation of each strain studied, its origin, its present taxonomic status, and the different methods used to study it are shown in Table 1. Unless otherwise stated, strains were grown for the different analyses on nutrient agar supplemented with $1 \%(\mathrm{wt} / \mathrm{vol})$ glucose $(\mathrm{pH}$ 7.4) (NAG) at $30^{\circ} \mathrm{C}$ for 24 to $48 \mathrm{~h}$; two exceptions were $P$. macquariensis, which was grown at $20^{\circ} \mathrm{C}$, and $P$. larvae subsp. larvae, which was grown on NAG supplemented with $1 \mathrm{mg}$ of thiamine hydrochloride per liter. The strains were checked for purity by plating and by microscopic examination and were maintained both as lyophilized cultures and as sporulated cultures on NAG slopes containing $5 \mathrm{mg}$ of $\mathrm{MnSO}_{4} \cdot 4 \mathrm{H}_{2} \mathrm{O}$ per liter (to enhance sporulation). The slopes were incubated for $48 \mathrm{~h}$ or longer, until spores were observed by microscopy, and then stored at $4^{\circ} \mathrm{C}$.

DNA preparation. Total genomic DNA was purified from cells grown on two plates by using a slight modification of the method of Pitcher et al. (32a), as described previously (15). The DNA preparations were visually inspected after $1 \%(\mathrm{wt} / \mathrm{vol})$ agarose gel electrophoresis, quantified spectrophotometrically at 260 $\mathrm{nm}$, and stored at $-20^{\circ} \mathrm{C}$.

ARDRA. Enzymatically amplified 16S rDNA was obtained from each strain by PCR, and this rDNA was analyzed by restriction digestion with five restriction enzymes (HaeIII, DpnII, RsaI, BfaI, and Tru9I) as described previously (15). The restriction patterns obtained for each strain were combined, and the combined normalized patterns were subjected to a numerical analysis with the Gelcompar 3.1 software by using the Dice coefficient and the unweighted pair group method with arithmetic average (UPGMA) clustering algorithm (15). The levels of reproducibility, which were determined by analyzing nine duplicate cultures at least twice, ranged from 92 to $100 \%$ (mean, $97 \%$ )

Gas chromatographic analysis of methylated fatty acids (FAME analysis). Cells were grown on Trypticase soy agar at $28^{\circ} \mathrm{C}$ for $24 \mathrm{~h}$ as recommended in the Microbial Identification System (Microbial ID, Inc., Newark, Del.) instructions. The medium used for $P$. larvae subsp. larvae was supplemented with $1 \mathrm{mg}$ of thiamine hydrochloride per liter, and the growth temperature was $37^{\circ} \mathrm{C}$. The methods used for fatty acid extraction, methyl ester preparation, and methyl ester separation by gas chromatography have been described previously (43). The fatty acid methyl ester (FAME) profiles were identified and clustered by using Microbial Identification System software version 3.8. The levels of reproducibility were very high, with the values for duplicate cultures that were analyzed at least twice falling below a Euclidian distance of 2.25 .

SDS-PAGE of whole-cell proteins. Cells used for sodium dodecyl sulfate (SDS)-polyacrylamide gel electrophoresis (PAGE) were obtained after $24 \mathrm{~h}$ of growth on NAG at $30^{\circ} \mathrm{C}$. For $P$. larvae subsp. larvae and $P$. larvae subsp. pulvifaciens, precultures grown on Columbia agar containing $5 \%$ (vol/vol) horse blood for $24 \mathrm{~h}$ at 37 and $30^{\circ} \mathrm{C}$, respectively, were used as inocula for growth on NAG. The methods used to prepare and electrophorese SDS protein extracts and to perform an UPGMA cluster analysis of the protein profiles have been described previously $(33,42)$. The levels of reproducibility were very high, with duplicate cultures that were analyzed at least twice exhibiting levels of similarity of at least $97 \%$.
Phenotypic characterization and numerical analysis. Most strains were cultivated on nutrient agar containing $5 \mathrm{mg}$ of $\mathrm{MnSO}_{4} \cdot 4 \mathrm{H}_{2} \mathrm{O}$ per liter; the exceptions were the $P$. larvae subsp. larvae and $P$. larvae subsp. pulvifaciens strains, which were grown on Columbia agar containing 5\% (vol/vol) horse blood at 37 and $30^{\circ} \mathrm{C}$, respectively. Strains were characterized by the methods of Logan and Berkeley (21) by using API tests and other phenotypic tests, and the data were recorded as described previously (14). The data were subjected to a numerical taxonomic analysis by using the GENSTAT 5 program. Levels of similarity, including negative matches in the API tests, were calculated by using the general similarity coefficient of Gower $\left(S_{\mathrm{G}}\right)(10)$, examined by performing an UPGMA cluster analysis, and expressed at $2.5 \%$ intervals. Nine strains were used throughout the study as duplicate cultures to give an indication of test consistency. These duplicate cultures and their homologous strains exhibited levels of similarity $\left(S_{\mathrm{G}}\right.$ values) ranging from 90 to $97.5 \%$ (mean, $93.9 \%$ ); this implied a probability of test error of about $3.0 \%$, which is acceptably low (20), especially since many of the characters were scored quantitatively.

Py-MS. Each strain was grown on duplicate plates containing nutrient agar. For $P$. larvae subsp. larvae and $P$. larvae subsp. pulvifaciens, precultures grown on Columbia agar containing $5 \%$ (vol/vol) horse blood for $24 \mathrm{~h}$ at 37 and $30^{\circ} \mathrm{C}$, respectively, were used as inocula for growth on nutrient agar. Three samples (one from one plate and two from the other) were removed for analysis. Preparation of the bacterial samples, pyrolysis mass spectrometry (Py-MS), and normalization and cluster analysis of the data by using the GENSTAT statistical software and the $S_{\mathrm{G}}$ were performed as described previously $(8,14)$.

RAPD analysis. Randomly amplified polymorphic DNA (RAPD) PCR and data analysis were carried out as described previously (14). The primers used were universal primer 76630 (5'TATGTAAAACGACGGCCAGT3') and primer 42423 (5'GGGCGTTGTCGGTGTTCATG3') (22).

\section{RESULTS AND DISCUSSION}

Overview of the polyphasic study of the genus Paenibacillus. The genus Paenibacillus, which was distinguished from the genus Bacillus mainly on the basis of the results of a 16S rRNA sequencing study (2), consists of several species, including recently described species and species which have been established for some years but for which there have been no comprehensive polyphasic data. A polyphasic approach aims at integrating all taxonomic information in a so-called consensus taxonomy (41) that reflects the natural relationships among organisms.

rRNA-based data (16S rRNA sequences, levels of DNArRNA hybridization) have gradually become accepted as data which can be used to infer natural or phylogenetic relationships $(26,47)$ and provide a general framework for classification. Recently, ARDRA has been shown to be a valuable technique for rapidly grouping organisms at the species level and above $(11,15,19,30,46)$. Hence, at the outset of this polyphasic study ARDRA was used to sort all of the strains into phylogenetic groups. In most cases the ARDRA groups obtained (Fig. 1A) corresponded very well to the currently recognized Paenibacillus species. Furthermore, these species were recovered in one large group at a similarity level of around $50 \%$ and were separated from representatives of other rRNA groups (1). This confirms that ARDRA grouping provides a reliable phylogenetic framework for delineating the genus Paenibacillus and for dividing this taxon into different species. However, the between-species relationships implied by the results of complete $16 \mathrm{~S}$ rRNA gene sequence analysis and ARDRA may differ. Indeed, although ARDRA as performed in this study allows only a partial (about $10 \%$ ) sequence analysis, this method is likely to reflect sequence information from multiple rRNA operons (15), as recommended by Clayton et al. (4) for phylogenetic analyses.

FAME analysis is very useful for obtaining descriptive information and can be used to cluster large sets of strains. If used with an appropriate database, FAME analysis data can result in identification of new isolates to at least the genus level for many taxa (45). The levels of taxonomic resolution, however, vary among taxa. The limitations of FAME analysis for identification of Bacillus species have been shown previously 
TABLE 1. Bacillus and Paenibacillus strains used and the methods used to characterize them

\begin{tabular}{|c|c|c|c|c|c|c|c|c|c|c|c|}
\hline \multirow[b]{2}{*}{ Name as received } & \multirow[b]{2}{*}{$\begin{array}{c}\text { Present } \\
\text { taxonomic status }{ }^{a}\end{array}$} & \multirow[b]{2}{*}{ Strain $^{b}$} & \multirow[b]{2}{*}{ Other designation(s) ${ }^{b}$} & \multirow[b]{2}{*}{ Source ${ }^{b}$} & \multicolumn{7}{|c|}{ Methods used } \\
\hline & & & & & ARDRA & $\begin{array}{l}\text { API } \\
\text { tests }^{c}\end{array}$ & $\begin{array}{l}\text { SDS- } \\
\text { PAGE }\end{array}$ & $\begin{array}{l}\text { FAME } \\
\text { analysis }\end{array}$ & $\begin{array}{c}\text { DNA } \\
\text { homologyd }\end{array}$ & $\begin{array}{l}\text { Py- } \\
\text { MS }\end{array}$ & $\begin{array}{l}\text { RAPD } \\
\text { analysis }\end{array}$ \\
\hline B. alvei & P. alvei & LMG $13253^{\mathrm{T}}$ & $\mathrm{B} 0016^{\mathrm{T}}, \mathrm{DSM} 29^{\mathrm{T}}$ & DSM & + & + & + & + & & + & + \\
\hline B. alvei & P. alvei & LMG 13254 & B0610, CN 2772 & Goodfellow & + & + & + & + & & + & + \\
\hline B. alvei & P. alvei & LMG 13255 & B0611, CN 2773 & Goodfellow & + & + & + & + & & + & + \\
\hline B. alvei & P. alvei & LMG 13256 & B0615, CN 3251 & Goodfellow & + & + & + & + & & + & + \\
\hline B. alvei & B. thiaminolyticus & LMG 13257 & B0711, NRRL NRS-1675 & Gordon & + & + & + & + & & + & + \\
\hline B. alvei & P. alvei & LMG 13258 & $\begin{array}{l}\text { B0810, NCIB } 8199, \\
\text { NRRL B-384 }\end{array}$ & NCIB & + & + & + & + & & + & + \\
\hline B. alvei & P. alvei & LMG 13259 & $\begin{array}{l}\text { B0811, NCIB 8212, } \\
\text { NRRL B-382 }\end{array}$ & NCIB & + & + & + & + & & + & + \\
\hline B. alvei & $P$. alvei & LMG 13260 & B0812, CCM 2411 & $\mathrm{CCM}$ & + & + & + & + & & + & + \\
\hline B. amylolyticus & P. amylolyticus & LMG $11153^{\mathrm{T}}$ & B1414 ${ }^{\mathrm{T}}$, DSM $3034^{\mathrm{T}}$ & DSM & + & + & + & + & & + & + \\
\hline B. amylolyticus & P. amylolyticus & LMG 14012 & B1384, NRRL B-717 & Nakamura & + & + & + & + & & + & + \\
\hline B. amylolyticus & P. amylolyticus & LMG 14013 & B1385, NRRL NRS-1136 & Nakamura & + & + & + & + & & + & + \\
\hline B. amylolyticus & P. amylolyticus & LMG 14457 & NCIMB 8144 & NCIMB & + & & + & + & & & \\
\hline B. azotofixans & P. azotofixans & LMG $14658^{\mathrm{T}}$ & $\mathrm{B} 1406^{\mathrm{T}}$, Seldin P3L5 ${ }^{\mathrm{T}}$ & Seldin & + & + & + & + & & + & + \\
\hline B. azotofixans & P. azotofixans & LMG 14659 & B1407, Seldin F-102 & Seldin & + & + & + & + & & + & + \\
\hline B. azotofixans & P. azotofixans & LMG 14660 & B1408, Seldin I-9 & Seldin & + & + & & & & + & + \\
\hline B. azotofixans & P. azotofixans & LMG 14661 & B1409, Seldin BE-1 & Seldin & + & + & + & + & & + & + \\
\hline B. brevis & B. brevis & LMG $16703^{T}$ & ATCC $8246^{\mathrm{T}}$ & ATCC & + & & & & & & \\
\hline B. cereus & B. cereus & LMG $6923^{\mathrm{T}}$ & $\operatorname{DSM} 31^{\mathrm{T}}$ & DSM & + & & & & & & \\
\hline B. circulans & B. circulans & LMG $13261^{\mathrm{T}}$ & $\mathrm{B} 0004^{\mathrm{T}}$, DSM $11^{\mathrm{T}}$ & DSM & + & & & & & & \\
\hline B. gordonae & P. validus & LMG $9817^{\mathrm{T}}$ & $\begin{array}{l}\text { B1395 }{ }^{\mathrm{T}} \text {, Pichinoty Q1 }{ }^{\mathrm{T}} \text {, } \\
\text { ATCC } 29948^{\mathrm{T}}\end{array}$ & ATCC & + & + & + & + & + & + & + \\
\hline B. gordonae & $P$. validus & LMG 14663 & B1400, Pichinoty Q3 & Pichinoty & + & + & + & + & & + & + \\
\hline B. gordonae & P. validus & LMG 14664 & B1401, Pichinoty Q12 & Pichinoty & + & + & + & + & & + & + \\
\hline B. gordonae & P. validus & LMG 14665 & B1402, Pichinoty Ipht 1 & Pichinoty & + & + & + & + & & + & + \\
\hline B. gordonae & $P$. validus & LMG 14666 & B1403, Pichinoty Pohb 1 & Pichinoty & + & + & + & + & + & + & + \\
\hline B. gordonae & $P$. validus & LMG 14667 & $\begin{array}{l}\text { B1404, Pichinoty Pohb } 3 \text {, } \\
\text { DSM } 6544\end{array}$ & Pichinoty & + & + & + & + & + & + & + \\
\hline B. gordonae & P. validus & LMG 14668 & B1405, Pichinoty Tri 5 & Pichinoty & + & + & + & + & + & + & + \\
\hline B. larvae & $\begin{array}{l}\text { P. larvae subsp. } \\
\text { larvae }\end{array}$ & LMG $9820^{\mathrm{T}}$ & $\mathrm{B} 1415^{\mathrm{T}}$, ATCC $9545^{\mathrm{T}}$ & ATCC & + & + & + & + & + & + & + \\
\hline B. larvae & $\begin{array}{l}\text { P. larvae subsp. } \\
\text { larvae }\end{array}$ & LMG 14425 & B1416, ATCC 25747 & ATCC & + & + & + & + & & + & + \\
\hline B. larvae & $\begin{array}{l}\text { P. larvae subsp. } \\
\text { larvae }\end{array}$ & LMG 14426 & B1417, ATCC 25748 & ATCC & + & + & + & + & + & + & + \\
\hline B. laterosporus & B. laterosporus & LMG $16000^{\mathrm{T}}$ & $\operatorname{DSM} 25^{\mathrm{T}}$ & DSM & + & & & & & & \\
\hline B. lautus & $P$. lautus & LMG $11157^{\mathrm{T}}$ & $\begin{array}{l}\text { B1396 }{ }^{\mathrm{T}}, \text { DSM } 3035^{\mathrm{T}}, \mathrm{B} . \\
\text { Henry } 160^{\mathrm{T}}\end{array}$ & DSM & + & + & + & + & & + & + \\
\hline B. lautus & P. lautus & LMG 14014 & B1387, NRRL NRS-678 & Nakamura $^{e}$ & & + & & & & + & + \\
\hline B. lautus & $P$. lautus & LMG 14015 & B1388, NRRL NRS-1171 & Nakamura & + & + & + & + & & + & + \\
\hline B. lautus & $P$. lautus & LMG 14669 & B1387, NRRL NRS-678 & Nakamura $^{e}$ & + & & + & + & & & \\
\hline "B. longisporus" & "B. longisporus" & LMG 13275 & B0986, Delaporte 15.F.9 & Gordon & + & + & + & + & & + & + \\
\hline "B. longisporus" & "B. longisporus" & LMG 13276 & B0989, Delaporte 51.A.5 & Gordon & + & + & + & + & & + & + \\
\hline "B. longisponus" & "B. longisporus" & LMG 13277 & B1006, Delaporte 57.D.3 & Gordon & + & + & + & + & & + & + \\
\hline "B. longisporus" & "B. longisporus" & LMG 14466 & $\begin{array}{l}\text { DSM 477, Delaporte } 15 \\
\text { H1 }\end{array}$ & DSM & + & & + & + & & & \\
\hline "B. longisporus" & "B. longisporus" & LMG 14467 & $\begin{array}{l}\text { DSM 478, Delaporte } 15 \\
\text { H4 }\end{array}$ & DSM & + & & + & + & & & \\
\hline B. macerans & P. macerans & LMG $13281^{\mathbf{T}}$ & B0497 ${ }^{\mathrm{T}}$, NCTC $6335^{\mathrm{T}}$ & NCTC & + & + & + & + & & + & + \\
\hline B. macerans & $P$. macerans & LMG 13282 & $\begin{array}{l}\text { B0027, Gibson 411, } \\
\text { NCTC } 7588\end{array}$ & NCTC & + & + & + & + & & & \\
\hline B. macerans & $P$. macerans & LMG 13283 & B0110, Gibson 557 & Gibson & + & + & + & + & & + & + \\
\hline B. macerans & P. macerans & LMG 13284 & B0111, Gibson 778 & Gibson & + & + & + & + & & + & + \\
\hline B. macerans & P. macerans & LMG 13285 & $\begin{array}{l}\text { B0198, Northrop 234A, } \\
\text { NCTC } 1068\end{array}$ & NCTC & + & + & + & + & & + & + \\
\hline B. macerans & P. macerans & LMG 13286 & B0276, NCTC 4743 & NCTC & + & + & + & + & & + & + \\
\hline B. macerans & P. pabuli & LMG 13287 & B0333 & Logan & + & + & + & + & & + & + \\
\hline B. macerans & P. macerans & LMG 13288 & B0904, Gibson 966 & Gibson & + & + & + & + & & + & + \\
\hline B. macquariensis & P. macquariensis & LMG $13289^{\mathrm{T}}$ & B0188 ${ }^{\mathrm{T}}$, NCTC $10419^{\mathrm{T}}$ & NCTC & + & + & + & + & & + & + \\
\hline B. macquariensis & P. macquariensis & LMG 13290 & B0189, NCTC 10420 & NCTC & + & + & + & + & & + & + \\
\hline B. macquariensis & P. macquariensis & LMG 13291 & B0190, NCTC 10421 & NCTC & + & + & + & + & & + & + \\
\hline B. pabuli & P. pabuli & LMG $11158^{\mathrm{T}}$ & B1418 ${ }^{\mathrm{T}}$, DSM $3036^{\mathrm{T}}$ & $\mathrm{DSM}^{e}$ & + & + & + & + & & + & \\
\hline B. pabuli & P. pabuli & LMG 13292 & B0317, Gibson 261 & Gibson & + & + & + & + & & + & + \\
\hline B. pabuli & P. pabuli & LMG 13293 & B0318, Gibson 287 & Gibson & + & + & + & + & & + & + \\
\hline B. pabuli & P. pabuli & LMG 14016 & B1389, NRRL B-745 & Nakamura & + & + & + & + & & + & + \\
\hline
\end{tabular}


TABLE 1-Continued

\begin{tabular}{|c|c|c|c|c|c|c|c|c|c|c|c|}
\hline \multirow[b]{2}{*}{ Name as received } & \multirow[b]{2}{*}{$\begin{array}{c}\text { Present } \\
\text { taxonomic status }\end{array}$} & \multirow[b]{2}{*}{ Strain $^{b}$} & \multirow[b]{2}{*}{ Other designation $(\mathrm{s})^{b}$} & \multirow[b]{2}{*}{ Source ${ }^{b}$} & \multicolumn{7}{|c|}{ Methods used } \\
\hline & & & & & ARDRA & $\begin{array}{l}\text { API } \\
\text { tests }^{c}\end{array}$ & $\begin{array}{l}\text { SDS- } \\
\text { PAGE }\end{array}$ & $\begin{array}{l}\text { FAME } \\
\text { analysis }\end{array}$ & $\begin{array}{c}\text { DNA } \\
\text { homology }^{d}\end{array}$ & $\begin{array}{l}\text { Py- } \\
\text { MS }\end{array}$ & $\begin{array}{l}\text { RAPD } \\
\text { analysis }\end{array}$ \\
\hline B. pabuli & P. pabuli & LMG 14017 & B1391, NRRL BD-536 & Nakamura & + & + & + & + & & + & + \\
\hline B. pabuli & P. pabuli & LMG 14671 & B1390, NRRL B-1488 & Nakamura & + & + & + & + & & & + \\
\hline B. pabuli & P. pabuli & LMG $15970^{\mathbf{T}}$ & ATCC $43899^{\mathrm{T}}$ & $\mathrm{ATCC}^{e}$ & + & & & & & & \\
\hline B. peoriae & $P$ peoriae & LMG $14832^{\mathrm{T}}$ & $\begin{array}{l}\text { B1423 }{ }^{\mathrm{T}}, \text { NRRL B- } \\
14750^{\mathrm{T}}\end{array}$ & Nakamura & + & + & + & + & & & \\
\hline B. polymyxa ${ }^{f}$ & P. peoriae & LMG 11649 & NRRL B-14477 & Nakamura & + & + & + & + & & & \\
\hline B. polymyxaf & P. polymyxa & LMG 11724 & B1412, NRRL NRS-1312 & Nakamura & + & + & + & + & & + & + \\
\hline B. peoriae & P. peoriae & LMG 14672 & B1413, NRRL B-14475 & Nakamura $^{e}$ & & + & & & & + & + \\
\hline B. peoriae & $P$. peoriae & LMG 16104 & NRRL NRS-1183 & Nakamura & & + & & & & & \\
\hline B. peoriae & $P$ peoriae & LMG 16108 & NRRL BD-54 & Nakamura & & + & & & & & \\
\hline B. peoriae & P. peoriae & LMG 16109 & NRRL BD-61 & Nakamura & & + & & & & & \\
\hline B. peoriae & $P$ peoriae & LMG 16111 & NRRL B-14475 & Nakamura $^{e}$ & + & & + & & & & \\
\hline B. polymyxa & P. polymyxa & LMG $13294^{\mathrm{T}}$ & B0011 ${ }^{\mathrm{T}}$, DSM $36^{\mathrm{T}}$ & DSM & + & + & + & + & & + & + \\
\hline B. polymyxa & P. polymyxa & LMG 13295 & B0107, Gibson 496 & Gibson & + & + & + & + & & + & + \\
\hline B. polymyxa & P. polymyxa & LMG 13296 & $\begin{array}{l}\text { B0264, T. Gibson 43, } \\
\text { NCTC } 7575\end{array}$ & Gibson & + & + & + & + & & + & + \\
\hline B. polymyxa & P. polymyxa & LMG 13297 & B0265, NCTC 4747 & NCTC & + & + & + & + & & + & + \\
\hline B. polymyxa & P. polymyxa & LMG 13298 & B0304, Gibson 965 & Gibson & + & + & + & + & & + & + \\
\hline B. polymyxa & P. polymyxa & LMG 13299 & B0316, Gibson 43 & Gibson & + & + & + & + & & + & + \\
\hline B. polymyxa & P. polymyxa & LMG 13300 & B0642, Ayres B57-3B & Goodfellow & + & + & + & + & & + & \\
\hline B. polymyxa & P. polymyxa & LMG 13301 & B0650, CN 2186 & Goodfellow & + & + & + & + & & + & + \\
\hline B. pulvifaciens & $\begin{array}{l}\text { P. larvae subsp. } \\
\text { pulvifaciens }\end{array}$ & LMG $6911^{\mathrm{T}}$ & $\mathrm{B} 1419^{\mathrm{T}}, \mathrm{NCIMB} 11201^{\mathrm{T}}$ & NCIMB & + & + & + & + & + & + & + \\
\hline B. pulvifaciens & $\begin{array}{l}\text { P. larvae subsp. } \\
\text { pulvifaciens }\end{array}$ & LMG 14427 & B1420, ATCC 25367 & ATCC & + & + & + & + & + & + & + \\
\hline B. pulvifaciens & $\begin{array}{l}\text { P. larvae subsp. } \\
\text { pulvifaciens }\end{array}$ & LMG 14428 & B1421, АTCC 25368 & ATCC & + & + & + & + & + & + & + \\
\hline B. pulvifaciens & $P$. macerans & LMG 13302 & B0302, Gibson 1301 & Gibson & + & + & + & + & & + & + \\
\hline B. pulvifaciens & P. macerans & LMG 13303 & B0307, Gibson 11.1301 & Gibson & + & + & + & + & & + & + \\
\hline B. subtilis & B. subtilis & LMG $7135^{\mathrm{T}}$ & DSM $10^{T}$ & DSM & + & & & & & & \\
\hline B. validus & P. validus & LMG $11161^{\mathrm{T}}$ & $\mathrm{B} 1397^{\mathrm{T}}, \mathrm{DSM} 3037^{\mathrm{T}}$ & DSM & + & + & + & + & + & + & + \\
\hline B. validus & $P$. validus & LMG 14018 & $\begin{array}{l}\text { B1392, NRRL NRS- } \\
\text { 838A }\end{array}$ & Nakamura & + & + & & & & + & + \\
\hline B. validus & P. validus & LMG 14019 & $\begin{array}{l}\text { B1393, NRRL NRS- } \\
\text { 839A }\end{array}$ & Nakamura & + & + & + & + & + & + & + \\
\hline B. validus & P. validus & LMG 14020 & B1394, NRRL NRS-625 & Nakamura & + & + & + & + & & + & + \\
\hline C. durum & P. durum & LMG 15706 & ATCC 27812 & АTCC & + & & & & & & \\
\hline C. durum & P. durum & LMG $15707^{\mathrm{T}}$ & ATCC $27763^{\mathrm{T}}$ & ATCC & + & & & & & & \\
\hline
\end{tabular}

${ }^{a}$ Including the results of this polyphasic study.

${ }^{b}$ ATCC, American Type Culture Collection, Rockville, Md.; B, N. A. Logan Bacillus Collection, Glasgow Caledonian University, Glasgow, United Kingdom; CCM, Czech Collection of Microorganisms, Masaryk University, Brno, Czech Republic; CN, Wellcome Collection of Microorganisms, Beckenham, Kent, United Kingdom; Delaporte, B. Delaporte Collection, University of Bristol, Bristol, United Kingdom; DSM, Deutsche Sammlung von Mikroorganismen und Zellkulturen, Braunschweig, Germany; Gibson, T. Gibson Collection, University of Bristol, Bristol, United Kingdom; Gordon, R. E. Gordon, Rutgers University, New Brunswick, N.J.; Goodfellow, M. Goodfellow, University of Newcastle, Newcastle-upon-Tyne, United Kingdom; Logan, N. A. Logan, Glasgow Caledonian University, Glasgow, United Kingdom; LMG, Laboratorium voor Microbiologie Collection, Universiteit Gent, Ghent, Belgium; Nakamura, L. K. Nakamura, U.S. Department of Agriculture, Peoria, Ill.; NCIMB, National Collection of Industrial and Marine Bacteria, Aberdeen, United Kingdom; NCTC, National Collection of Type Cultures, Central Public Health Laboratory, London, United Kingdom; NRRL, Northern Regional Research Laboratory Collection, Peoria, Ill.; Pichinoty, F. Pichinoty, UER Scientifique de Luminy, Marseille, France; Seldin, L. Seldin, Universidade Federal do Rio de Janeiro, Rio de Janeiro, Brazil; NCIB, National Collection of Industrial Bacteria, Aberdeen, United Kingdom.

${ }^{c}$ API system tests, other biochemical tests, and morphological observations.

${ }^{d}$ Data from references 13 and 14

e Two independent subcultures of this strain were deposited in the Laboratorium voor Microbiologie Collection on different occasions.

${ }^{f}$ Received as B. polymyxa but reclassified as $B$. peoriae by Montefusco et al. (25).

(18). Consistent with the results of Kämpfer (18), the results of the numerical analysis of our FAME data assigned the strains mainly to species groups (clusters Ia-c and IIa-c in Fig. 2) that were defined at a Euclidian distance of 13 (which within other bacterial taxa is for the most part used for species delineation) or lower. These species groups occurred in two major clusters, at a Euclidian distance of about 20 (Fig. 2). Furthermore, the species compositions of the major FAME clusters corresponded fairly well to the species compositions of the two major ARDRA clusters defined at a level of similarity of around $60 \%$ (Fig. 1A). The exceptions were the different po- sitions of $P$. macquariensis and $P$. larvae subsp. pulvifaciens. The position of the former organism may be explained by the nonoptimal growth temperature $\left(28^{\circ} \mathrm{C}\right)$ used in the FAME analysis of this psychrotrophic species.

Phenotypic analyses, in which morphological, physiological, and biochemical characteristics are determined, remain the basis for descriptions of taxa, and the results of these analyses allow workers to construct identification schemes. Furthermore, it has been emphasized that phylogenetically based taxonomic schemes should also exhibit phenotypic consistency $(26,44)$. However, in the phenogram based on a numerical 


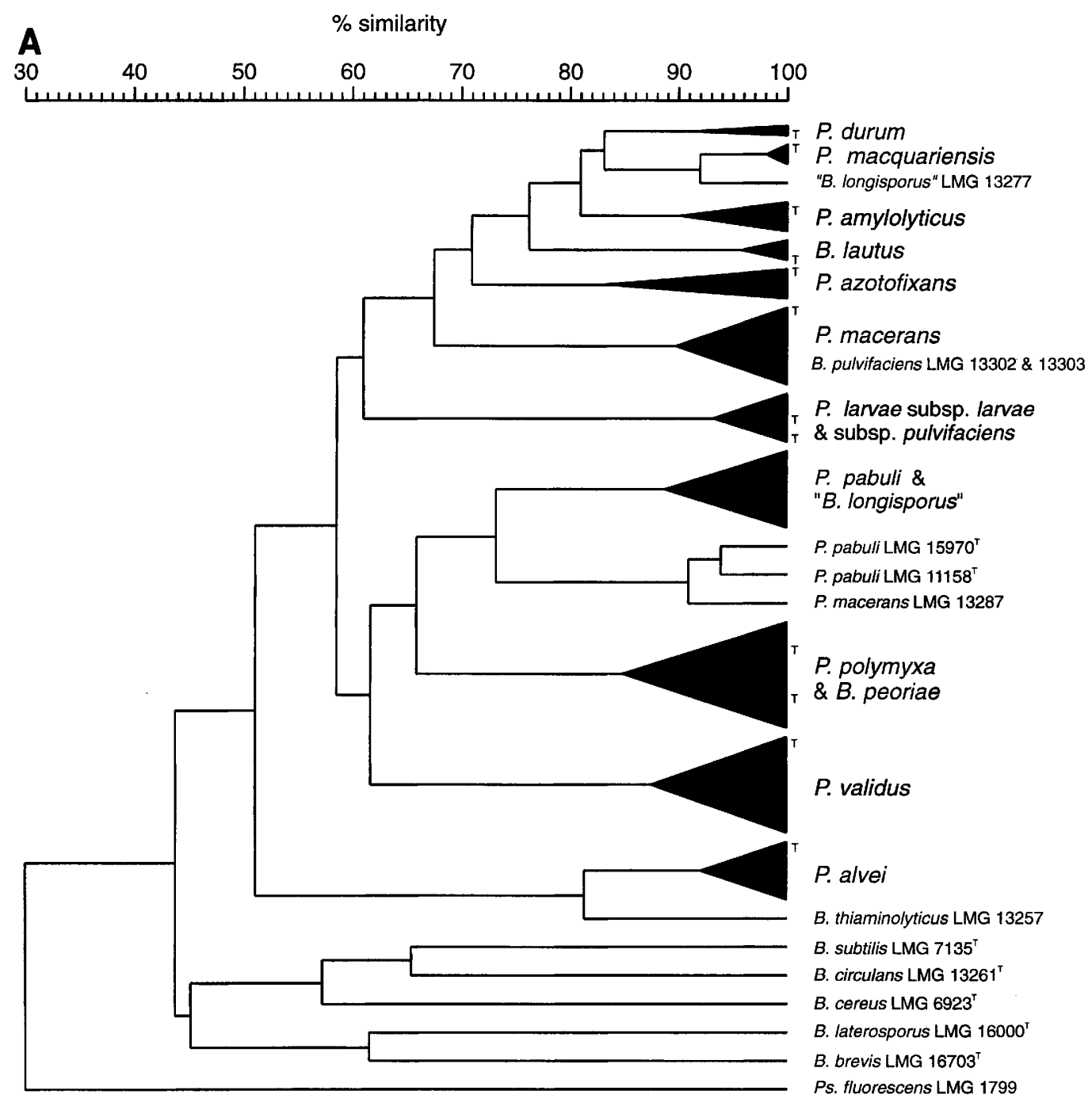

FIG. 1. (A) Simplified dendrogram based on UPGMA clustering of similarity coefficients of normalized combined 16S rDNA restriction profiles (as determined by ARDRA) of representatives of 10 Paenibacillus species and of the related species $B$. peoriae, B. lautus, and "B. longisporus." The restriction enzymes used were HaeIII, DpnII, RsaI, BfaI, and Tru9I. Representatives of Bacillus rRNA groups 1 and 4 and Pseudomonas fluorescens LMG 1799 were used as outgroup reference organisms. T indicates the position of a type strain. (B) Normalized computer profiles of restriction fragments of amplified 16S rDNAs of several Paenibacillus and Bacillus species generated by the enzymes indicated at the top. Lane M contained the molecular weight marker. Abbreviations: P., Paenibacillus; B., Bacillus; Ps., Pseudomonas.

analysis of the results of API tests and other phenotypic observations (Fig. 3), some species formed distinct clusters, while others (e.g., $P$. amylolyticus and $P$. pabuli) belonged to composite clusters. It is not surprising that phenotypic clusters do not always reflect phylogenetic relationships for various reasons, such as convergent evolution and differences in evolutionary rates, but this does not necessarily mean that phenotypic characteristics that distinguish the genotypic groups are absent (Table 2).

High-resolution phenotypic fingerprinting techniques, such as SDS-PAGE of whole-cell proteins or Py-MS, can be very useful for delineating groups at species and subspecies levels. With SDS-PAGE large sets of closely related strains can be recovered in numerical groups that for the most part exhibit high levels of correlation with DNA-DNA hybridization results (33). In the general phenogram based on a numerical analysis of the total SDS-PAGE profiles (Fig. 4), several clusters indeed corresponded to ARDRA clusters representing recog- nized species, while representatives of some species (e.g., $P$. alvei and $P$. pabuli) were located in more than one SDS-PAGE group. Findings such as the latter finding are usually indications of intraspecific variation, but sometimes the real levels of similarity between overall protein profiles are masked or disturbed by the dominance of one or more irregular dense protein bands (6). The exclusion of such bands from numerical analyses (Fig. 4, arrows) often allows more meaningful groups to be obtained.

The Py-MS technique, in which the total chemical composition of bacterial cells is examined, is likewise useful for differentiating closely related species and for revealing infraspecific variations (12). In the dendrogram based on Py-MS data (Fig. 5), most of the species were represented by well-defined, homogeneous clusters, but members of some species (e.g., $P$. alvei and $P$. pabuli) showed between-strain variation and apparently related strains of each of these species were recovered in more than one cluster. 

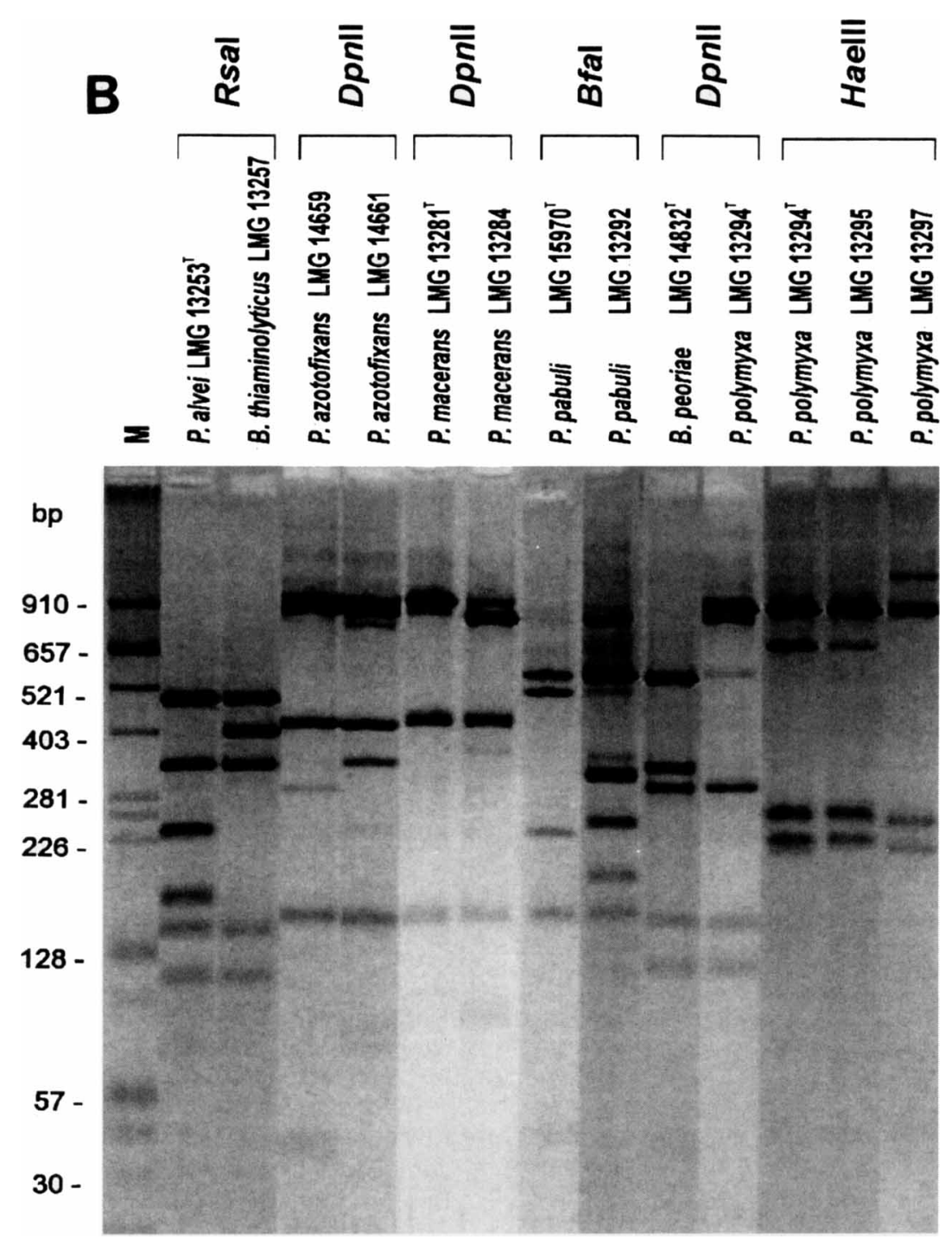

FIG. 1-Continued.

RAPD analysis was initially used to subtype species; however, although the results of RAPD analysis are highly primer dependent, several studies have shown that species-specific DNA fragments are generated (40). In the present study, the universal primer yielded tighter species clusters and better species separation than primer 42423 yielded (Fig. 6).

Detailed polyphasic taxonomy of the recognized Paenibacillus species and related Bacillus species. (i) $P$. alvei. $P$. alvei appeared to be a phylogenetically homogeneous species which occurred at the border of the genus Paenibacillus on the ARDRA dendrogram (Fig. 1A). This species was also distinct from most other Paenibacillus species as determined by the FAME analysis (Fig. 2) and by API and other phenotypic tests (Fig. 3), and it was easily distinguished from other species in the genus (Table 2). However, API and other phenotypic tests (Fig. 3) and SDS-PAGE (Fig. 4) revealed that there were two phenotypic groups, whose members were the same except for one strain. The exception was LMG 13254, which occurred in the type strain cluster in the former analysis, but was an outlier of the cluster that did not contain the type strain on the SDSPAGE dendrogram. The group identified by API and other phenotypic tests was also identified by the RAPD analysis when the universal primer was used (Fig. 6A). On the Py-MS dendrogram (Fig. 5), seven strains of $P$. alvei exhibited heterogeneity and occurred in distant clusters whose members were different from the members of the clusters identified on the basis of API, SDS-PAGE, and RAPD data. Nakamura (29) identified two DNA homology groups with a minimum level of DNA relatedness of $60 \%$ among his $B$. alvei strains. The following three strains included in this study were also studied by Nakamura (29): DNA group 1 strains LMG 13258 and LMG 13259 and DNA group 2 strain LMG $13253^{\mathrm{T}}$ ( $\mathrm{T}=$ type strain). These data and our data confirm the limited heterogeneity of P. alvei.

One strain, LMG 13257, was an outlier of the $P$. alvei cluster as determined by ARDRA (Fig. 1A); this strain produced slightly different patterns with RsaI (Fig. 1B), BfaI, and Tru9I than the other $P$. alvei strains produced. It was also distinct from the $P$. alvei clusters as determined by the FAME (Fig. 2), SDS-PAGE (Fig. 4), and Py-MS (Fig. 5) analyses and by the RAPD analysis when the universal primer was used (Fig. 6A), and, along with its duplicate culture, it was an outlier of one of 


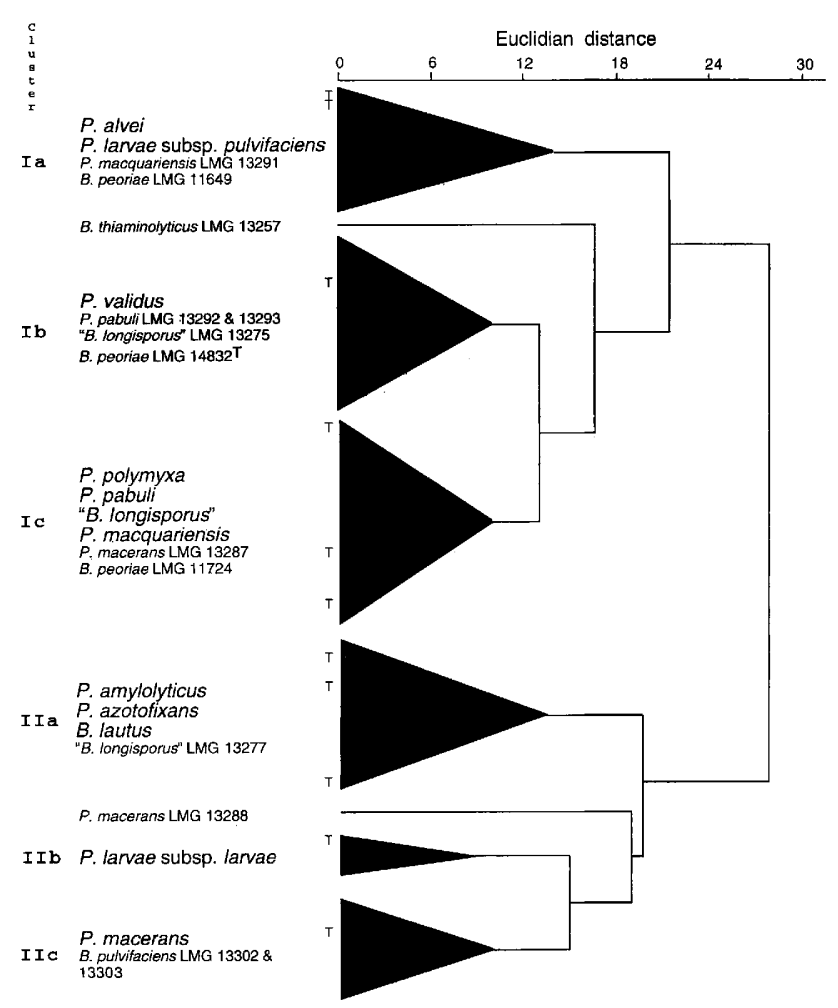

FIG. 2. Simplified dendrogram based on UPGMA clustering of Euclidian distances between fatty acid profiles (as determined by FAME analysis) of representatives of nine Paenibacillus species and of the related species $B$. peoriae, $B$. lautus and " $B$. longisporus." $T$ indicates the position of a type strain. The major fatty acids found in several clusters were as follows (the mean concentration and range of concentrations of each compound are indicated in parentheses): cluster $\mathrm{Ia}, 14: 0$ iso $(0.7 \%, 0$ to $2.7 \%), 14: 0(3.6 \%, 1.4$ to $10.4 \%), 15: 0$ iso $(16.3 \%, 10.6$ to $21.9 \%), 15: 0$ anteiso $(42.5 \%, 35.5$ to $48.5 \%), 15: 0(2.0 \%, 0$ to $8.1 \%), 16: 0$ iso $(2.9 \%, 0.8$ to $6.3 \%), 16: 1 \omega 11 \mathrm{c}(4.2 \%, 0$ to $9.4 \%), 16: 0(13.1 \%, 5.8$ to $19.7 \%)$, iso $17: 1 \omega 10 \mathrm{c}(0.7 \%, 0$ to $2.5 \%), 17: 0$ iso $(5.8 \%, 0.6$ to $10.2 \%)$, and $17: 0$ anteiso $(6.4 \%, 0.5$ to $13.1 \%)$; cluster $\mathrm{Ib}, 10: 0(0.65 \%, 0$ to $1.3 \%), 14: 0$ iso $(3.3 \%, 2.7$ to $5.1 \%), 14: 0(2.9 \%, 1.5$ to $7.3 \%), 15: 0$ iso $(12.8 \%, 9.7$ to $15.3 \%), 15: 0$ anteiso $(52.0 \%, 50.3$ to $55.1 \%), 15: 0(0.75 \%, 0$ to $1.7 \%), 16: 1 \omega 7 \mathrm{c}$ alcohol $(2.0 \%, 0$ to $3.1 \%), 16: 0$ iso $(5.6 \%, 2.3$ to $7.5 \%), 16: 1 \omega 11 \mathrm{c}(6.4 \%, 1.3$ to $11.1 \%), 16: 0(5.5 \%$, 3.7 to $10.4 \%)$, iso $17: 1 \omega 10 \mathrm{c}(0.85 \%, 0$ to $1.4 \%), 17: 0$ iso $(3.0 \%, 1.1$ to $6.5 \%)$, and $17: 0$ anteiso $(3.6 \%, 1.6$ to $5.9 \%)$; cluster Ic, $14: 0$ iso $(2.8 \%, 1.0$ to $5.5 \%), 14: 0$ $(3.4 \%, 1.5$ to $7.0 \%), 15: 0$ iso $(8.1 \%, 6.2$ to $12.9 \%), 15: 0$ anteiso $(61.2 \%, 54.7$ to $66.8 \%), 15: 0(0.8 \%, 0$ to $4.3 \%), 16: 0$ iso $(5.2 \%, 2.1$ to $8.1 \%), 16: 1 \omega 11 \mathrm{c}(3.6 \%, 1.2$ to $7.2 \%), 16: 0(7.8 \%, 3.6$ to $12.0 \%), 17: 0$ iso $(1.95 \%, 0.8$ to $3.6 \%)$, and $17: 0$ anteiso $(4.25 \%, 1.1$ to $9.2 \%)$; cluster IIa, $14: 0$ iso $(2.8 \%, 1.2$ to $5.9 \%), 14: 0(5.5 \%$, 2.3 to $9.6 \%), 15: 0$ iso $(5.9 \%, 3.5$ to $8.7 \%), 15: 0$ anteiso $(45.2 \%, 37.6$ to $52.0 \%)$, $15: 0(0.8 \%, 0$ to $2.2 \%), 16: 0$ iso $(6.9 \%, 3.7$ to $10.7 \%), 16: 1 \omega 11 \mathrm{c}(1.0 \%, 0$ to $3.5 \%), 16: 0(23.4 \%, 18.9$ to $31.0 \%), 17: 0$ iso $(2.4 \%, 0$ to $4.2 \%)$, and $17: 0$ anteiso $(5.5 \%, 1.1$ to $9.5 \%)$; cluster IIb, $14: 0$ iso $(0.5 \%, 0$ to $0.85 \%), 14: 0(1.95 \%, 1.7$ to $2.5 \%), 15: 0$ iso $(12.6 \%, 10.2$ to $14.5 \%), 15: 0$ anteiso $(28.1 \%, 26.8$ to $28.9 \%), 15: 0$ $(1.2 \%, 0$ to $3.0 \%), 16: 0$ iso $(5.2 \%, 4.5$ to $5.7 \%), 16: 0(22.3 \%, 20.7$ to $25.1 \%), 17: 0$ iso $(9.6 \%, 6.5$ to $11.2 \%), 17: 0$ anteiso $(13.2 \%, 10.9$ to $14.3 \%), 17: 0(1.0 \%, 0$ to $2.1 \%), 18: 0(0.7 \%, 0$ to $1.1 \%)$, and summed feature $4(3.6 \%, 3.4$ to $3.8 \%)$ (summed feature 4 is 15:0 iso $2 \mathrm{OH}$ and/or 16:1 $\omega 7 \mathrm{c})$; cluster IIc, $12: 0(1.0 \%, 0.4$ to $2.55 \%), 14: 0$ iso $(4.7 \%, 3.2$ to $6.85 \%), 14: 0(6.8 \%, 4.35$ to $9.2 \%), 15: 0$ iso $(9.6 \%, 8.7$ to $10.3 \%), 15: 0$ anteiso $(32.1 \%, 30.1$ to $33.8 \%), 15: 0(1.1 \%, 0.8$ to $1.6 \%), 16: 0$ iso $(12.1 \%, 10.5$ to $13.7 \%), 16: 0(20.2 \%, 13.1$ to $24.1 \%), 17: 0$ iso $(5.4 \%, 3.0$ to $6.6 \%)$, and $17: 0$ anteiso $(6.9 \%, 4.0$ to $9.1 \%)$.

the $P$. alvei clusters on the phenogram based on the results of API and other phenotypic tests (Fig. 3). According to Nakamura (29), this strain belongs to the revived species Bacillus thiaminolyticus. Although no $16 \mathrm{~S}$ rRNA sequence is available and the type strain was not included at the beginning of this polyphasic study, our data strongly suggest that $B$. thiaminolyticus belongs to the genus Paenibacillus.

(ii) P. amylolyticus. The four $P$. amylolyticus strains studied clustered together in all of our analyses (Fig. 1 through 6), indicating that this species is genotypically and phenotypically homogeneous. The ARDRA data (Fig. 1A) suggested that this organism is closely related to $P$. azotofixans, $P$. durum, $B$. lautus, and $P$. macquariensis. The close relationship to $P$. macquariensis based on ARDRA data is consistent with the findings of Ash et al. (1), who determined the complete 16S rRNA sequences of the type strains of the organisms. All of the FAME data except the data for $P$. macquariensis (and $P$. $d u$ rum, which was not included in the FAME analysis) were consistent with the ARDRA clustering (Fig. 2). In the numerical analysis of the data obtained from API and other phenotypic tests, the $P$. amylolyticus strains were recovered in a composite cluster at an $S_{\mathrm{G}}$ value of $85 \%$ that contained representatives of $P$. pabuli, " $B$. longisporus," and B. lautus and joined with $P$. macquariensis at an $S_{\mathrm{G}}$ value of $82.5 \%$ (Fig. 3 ). Nevertheless, $P$. amylolyticus could be distinguished from these other species by several characteristics (Table 2). A close phenotypic relationship with $P$. pabuli (but not with the type strain of this species) was also apparent from the results of the Py-MS analysis (Fig. 5).

(iii) $\boldsymbol{P}$. azotofixans. The four $P$. azotofixans strains studied exhibited high levels of genotypic and phenotypic homogeneity (Fig. 1 through 6), which allowed easy differentiation of this species from other Paenibacillus species on the basis of routine phenotypic characteristics (Table 2). In contrast to the homogeneity of some of the chemotaxonomic data (Fig. 2 and 5), in the ARDRA some enzymes produced strain-specific bands (e.g., the DpnII bands in Fig. 1B). As described above, on the ARDRA dendrogram the $P$. azotofixans cluster belonged to a species group containing $B$. lautus, $P$. amylolyticus, $P$. macquariensis, and $P$. durum, and $P$. macerans was the closest neighbor (Fig. 1A). The FAME data ( $P$. durum was not included in the FAME analysis) likewise indicated that $P$. azotofixans was closely related to $B$. lautus and $P$. amylolyticus and that $P$. macerans was more distantly related (Fig. 2).

(iv) $\boldsymbol{P}$. durum. The aerotolerant anaerobic species $P$. durum, which formerly was named $C$. durum, was reclassified (5) as $P$. durum on the basis of $16 \mathrm{~S}$ rDNA sequence data. We included the two available $P$. durum strains only in our ARDRA (Fig. 1A), and in this analysis these organisms clustered together at a similarity level of $91 \%$ in the species group containing $P$. macquariensis, $P$. azotofixans, B. lautus, and " $B$. longisporus" LMG 13277. This finding is consistent with the data of Collins et al. (5), who also found a high level of phylogenetic relatedness to $P$. azotofixans (level of $16 \mathrm{~S}$ rDNA sequence similarity, $98 \%)$.

(v) P. larvae. Previously (13), we showed that $P$. pulvifaciens is a later synonym of $P$. larvae because these organisms have identical ARDRA patterns (Fig. 1A) and the level of DNA relatedness between the type strains is more than $90 \%$. However, the two taxa could be clearly differentiated on the basis of FAME data (Fig. 2) and SDS-PAGE analysis data (the dense protein band indicated by arrow 1 in Fig. 4) and formed two separate but closely linked clusters as determined by the other numerical analyses (Fig. 3, 5, and 6). Taking into consideration this evidence and differences between the two taxa in honey bee pathogenicity, we proposed that they should be reclassified as $P$. larvae subsp. larvae and $P$. larvae subsp. pulvifaciens.

In the present study, strains LMG 13302 and LMG 13303, which were labelled $B$. pulvifaciens in the Gibson collection, behaved like $P$. macerans strains (see below).

(vi) B. lautus. On the ARDRA dendrogram (Fig. 1A) the three $B$. lautus strains studied (including the type strain) formed a tight cluster at a level of similarity of $96 \%$, joined $P$. macquariensis, $P$. amylolyticus, $P$. durum, and " $B$. longisporus" 


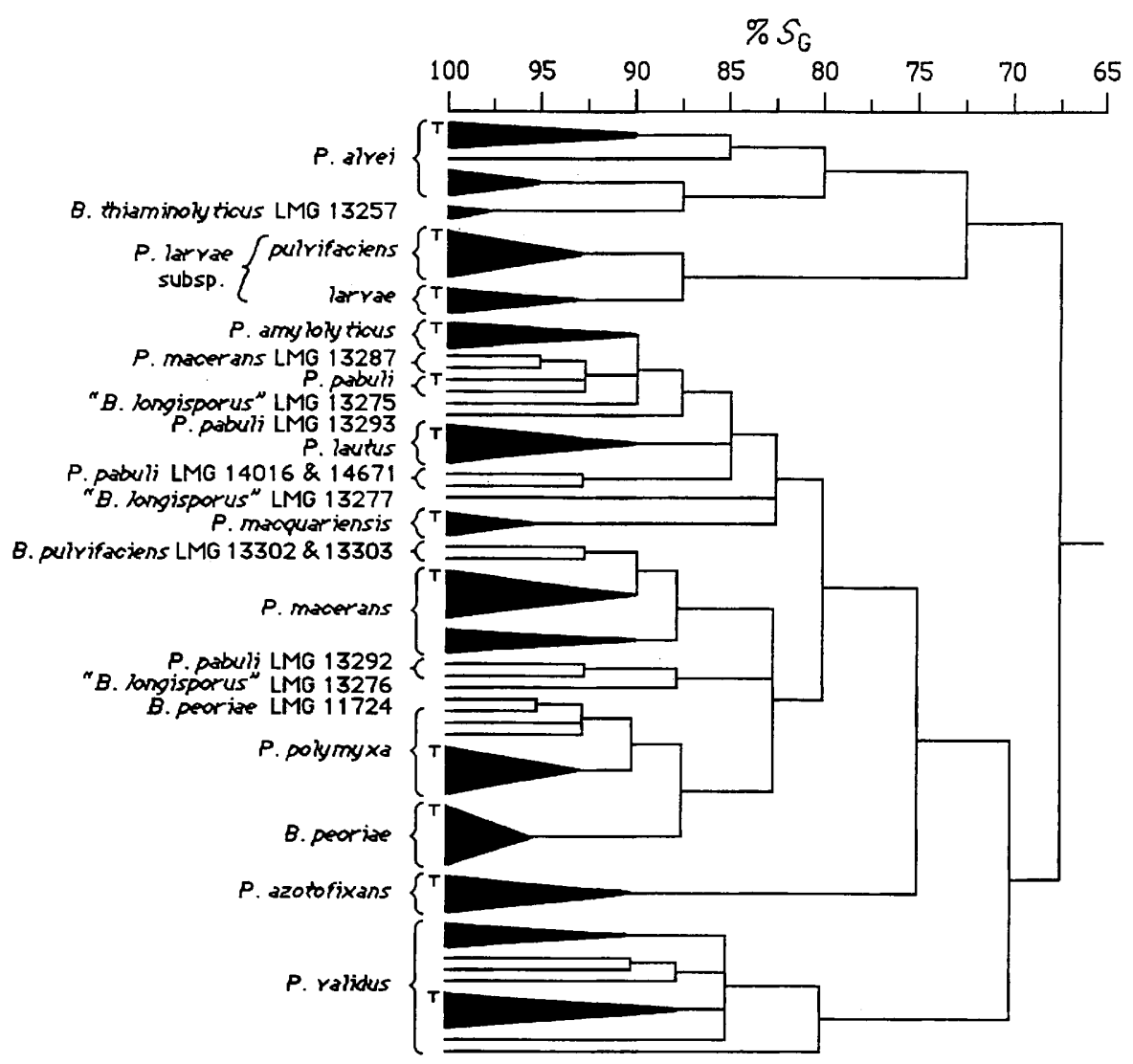

FIG. 3. Simplified phenogram based on UPGMA clustering of similarity coefficients ( $S_{\mathrm{G}}$ values) of 87 phenotypic characteristics of representatives of nine Paenibacillus species and of the related species B. peoriae, B. lautus, and "B. longisporus." $T$ indicates the position of a type strain.

LMG 13277 at a level of similarity of $76 \%$, and were clearly separated from rRNA group 1 and group 4 (1) representatives. B. lautus is thus clearly a member of the Paenibacillus rRNA group. The relationships implied by the ARDRA data were supported by the FAME dendrogram, in which the $B$. lautus strains clustered together with $P$. azotofixans, $P$. amylolyticus, and " $B$. longisporus" LMG 13277 (cluster IIa in Fig. 2). These findings contradict the placement of this species in Bacillus rRNA group 1 (1), a result that was obtained on the basis of the $16 \mathrm{~S}$ rRNA sequence of the type strain alone. In a previous paper (15), we noted the discrepancy between the restriction sites determined experimentally with amplified 16S rDNA of the B. lautus type strain and the restriction sites inferred from the 16S rRNA sequence obtained from Ribosomal Database Project database (22a). The assignment of two other $B$. lautus strains to the same ARDRA group in this paper seriously questions the authenticity of the type strain used for sequence analysis (1).

The analysis of data obtained from API and other phenotypic tests revealed appreciable between-strain variation. The strains examined, including a duplicate of the type strain, formed a somewhat loose cluster at an $S_{\mathrm{G}}$ value of $90 \%$, and this cluster merged with $P$. amylolyticus and representatives of $P$. pabuli at an $S_{\mathrm{G}}$ value of $85 \%$ (Fig. 3). Despite the phenotypic heterogeneity implied by the results of this analysis, the raw data permit differentiation of $B$. lautus from other members of the genus Paenibacillus (Table 2).

On the SDS-PAGE and RAPD dendrograms (Fig. 4 and 6), LMG $11157^{\mathrm{T}}$ and LMG 14669 (= LMG 14014) clustered together, while LMG 14015 occurred separately. However, visual inspection revealed that the SDS-PAGE profiles appeared to be similar except for an irregular band pattern in the highestmolecular-weight zone, which disturbed the numerical analysis. When this zone (corresponding to a molecular weight of more than $8.3 \times 10^{4}$; indicated by arrow 1 in Fig. 4) was excluded, the three strains formed a single cluster at a level of similarity of $82 \%$ (data not shown), which probably corresponded to the species level. On the Py-MS dendrogram the strains formed a tight cluster which merged with the $P$. macquariensis cluster, the type strain of $P$. pabuli, and strains of " $B$. longisporus" (Fig. 5).

In short, our analyses indicated that $B$. lautus is closely related to the genus Paenibacillus, and the correspondence between the phylogenetic and phenetic relationships of three $B$. lautus strains indicates that this organism should be reclassified as Paenibacillus lautus comb. nov. Because of this reclassification, the 16S rRNA (or rDNA) sequence of at least the type strain must be redetermined. The emended description below is based on data from the present study and on the data of Nakamura (27), which were obtained by using the methods of Gordon et al. (9).

(vii) Emended description of Paenibacillus lautus comb. nov. Paenibacillus lautus (lau'tus. L. part. adj. lautus, washed, splendid). Motile, gram-positive rods with round ends that are 0.5 to $1.0 \mu \mathrm{m}$ wide by 4.0 to $7.0 \mu \mathrm{m}$ long and occur singly and in pairs. Sporangia are regular and are swollen by subterminal ellipsoidal spores.

Facultatively anaerobic and catalase positive. The organism grows on routine media, such as nutrient agar, producing circular to irregularly shaped, low convex, greyish colonies (which 
TABLE 2. Characteristics that differentiate Paenibacillus species

\begin{tabular}{|c|c|c|c|c|c|c|c|c|c|c|c|c|}
\hline Characteristic $^{a}$ & $\begin{array}{c}P . \\
\text { polymyxa }\end{array}$ & $\begin{array}{c}P . \\
\text { amylolyticus }\end{array}$ & $\underset{\text { lautus }}{P .}$ & $\begin{array}{c}P . \\
\text { macquariensis }\end{array}$ & $\begin{array}{c}P . \\
\text { pabuli }\end{array}$ & $\begin{array}{c}P . \\
\text { peoriae }\end{array}$ & $\begin{array}{c}P . \\
\text { macerans }\end{array}$ & $\begin{array}{c}P . \\
\text { alvei }^{b}\end{array}$ & $\begin{array}{l}P . \text { larvae } \\
\text { subsp. } \\
\text { larvae }\end{array}$ & $\begin{array}{l}\text { P. larvae } \\
\text { subsp. } \\
\text { pulvifaciens }\end{array}$ & $\begin{array}{c}P . \\
\text { validus }\end{array}$ & $\begin{array}{c}P . \\
\text { azotofixans }\end{array}$ \\
\hline Swollen sporangia $^{c}$ & $t^{c}$ & + & $+t$ & ++ & + & + & ++ & + & + & + & +++ & + \\
\hline Anaerobic growth & + & + & + & + & + & + & + & + & + & + & - & + \\
\hline Casein hydrolysis & + & - & $\mathbf{v}$ & - & $\mathrm{v}$ & + & - & + & + & + & - & - \\
\hline $\mathrm{ONPG}^{d}$ hydrolysis & + & + & + & + & + & + & + & + & - & - & - & + \\
\hline Arginine dihydrolase & - & - & - & - & - & - & - & - & - & + & _- & - \\
\hline Indole production & - & - & - & - & - & - & - & + & - & - & - & - \\
\hline Gelatin liquefaction & + & - & - & - & + & + & $\mathrm{v}$ & + & + & + & - & - \\
\hline Nitrate reduction & $\mathrm{v}$ & + & - & - & - & $\mathrm{v}$ & - & - & $\mathrm{v}$ & $\mathbf{v}$ & $\mathbf{v}$ & - \\
\hline $\begin{array}{l}\text { Gas produced from } \\
\text { carbohydrates }\end{array}$ & + & - & - & - & - & + & + & - & - & - & - & + \\
\hline \multicolumn{13}{|l|}{ Acid produced from: } \\
\hline Glycerol & + & - & + & - & + & $\mathrm{v}$ & + & + & + & + & + & - \\
\hline D-Arabinose & - & - & + & - & - & - & + & - & - & - & - & - \\
\hline L-Arabinose & + & + & + & - & + & + & + & - & - & - & - & - \\
\hline Ribose & + & + & + & + & + & + & + & + & + & + & + & - \\
\hline D-Xylose & + & + & + & + & + & + & + & - & - & - & + & - \\
\hline Adonitol & - & - & - & - & - & - & - & + & - & - & - & - \\
\hline Methylxyloside & + & + & + & + & + & + & + & - & - & - & - & - \\
\hline D-Fructose & + & + & + & + & + & + & + & - & - & - & + & + \\
\hline Mannitol & + & - & + & + & + & + & + & - & - & + & + & + \\
\hline Methyl-D-mannoside & - & + & - & - & $\mathrm{v}$ & + & $\mathrm{v}$ & - & - & - & - & - \\
\hline Salicin & + & + & + & + & + & + & + & $\mathrm{v}$ & + & - & - & + \\
\hline Maltose & + & + & + & + & + & + & + & + & - & - & + & + \\
\hline D-Trehalose & + & + & + & + & + & - & + & $\mathrm{v}$ & + & + & + & + \\
\hline Gentiobiose & + & + & + & + & + & + & + & + & - & - & - & + \\
\hline 2-Keto-D-gluconate & - & - & - & - & - & - & - & - & - & - & - & + \\
\hline 5-Keto-D-gluconate & - & - & - & - & - & - & - & - & - & - & - & + \\
\hline
\end{tabular}

${ }^{a}$ With the exception of spore morphology, anaerobic growth, and casein hydrolysis, all characteristics were determined by using API 20E and API 50CHB System tests.

${ }^{b} B$. thiaminolyticus LMG 13257 , which was received as $B$. alvei, could be distinguished from $P$. alvei strains by its production of $\mathrm{H}_{2} \mathrm{~S}$ in API $20 \mathrm{E}$ strips.

$c+$, positive or slightly to moderately swollen; ++ , moderately to greatly swollen; +++ , greatly swollen; - , negative; $v$, variable.

${ }^{d} \mathrm{ONPG}, o$-nitrophenyl- $\beta$-D-galactopyranoside.

become white as the cells sporulate) that are 1 to $2 \mathrm{~mm}$ in diameter after incubation for 2 to 3 days at $30^{\circ} \mathrm{C}$; the colonies have a thin butyrous consistency and may have a tendency to spread across the agar surface with microcolonies. The optimum growth temperature is 28 to $30^{\circ} \mathrm{C}$, the maximum temperature is 45 to $50^{\circ} \mathrm{C}$, and the minimum temperature is 5 to $10^{\circ} \mathrm{C}$.

$o$-Nitrophenyl- $\beta$-D-galactopyranoside is hydrolyzed, and the Voges-Proskauer reaction is positive, but citrate is not utilized, gelatin is not hydrolyzed, nitrate is not reduced, and arginine dihydrolase, hydrogen sulfide, urease, and indole are not produced as determined with API 20E strips. Nakamura (27) has reported positive reactions for nitrate reduction and urease.

In API 50CH galleries, when API CHB suspension medium is used, esculin is hydrolyzed, and acid, but no gas, is produced from the following compounds: amygdalin, arbutin, D- and L-arabinose, D-cellobiose, D-fructose, galactose, gentiobiose, Dglucose, glycerol, glycogen, lactose, maltose, D-mannose, mannitol, D-melibiose, methyl-D-glucoside, methylxyloside, $N$-acetylglucosamine, D-raffinose, ribose, salicin, starch, sucrose, D-trehalose, D-turanose, and D-xylose. Acid is not produced from adonitol, D- and L-arabitol, dulcitol, erythritol, D-fucose, 2-keto-D-gluconate, 5-keto-D-gluconate, D-lyxose, meso-inositol, methyl-D-mannoside, rhamnose, sorbitol, L-sorbose, D-ta- gatose, xylitol, and L-xylose. Different strains give different results with $\mathrm{L}$-fucose, gluconate, inulin, and D-melezitose. Nakamura (27) reported a positive result for L-rhamnose fermentation.

The following fatty acids are present and account for more than $1 \%$ of the total fatty acid content: $14: 0$ iso, 14:0, 15:0 iso, $15: 0$ anteiso, $16: 0$ iso, 16:1 $\omega 11 \mathrm{c}, 16: 0,17: 0$ iso, and 17:0 anteiso.

Casein is weakly hydrolyzed by some strains, growth is not inhibited by $5 \% \mathrm{NaCl}$, and $5 \%$ horse blood agar is not hemolyzed.

The average $\mathrm{G}+\mathrm{C}$ content is $51 \mathrm{~mol} \%$ as determined by the buoyant density method (27). The ARDRA patterns of the strains obtained with HaeIII, DpnII, RsaI, BfaI, and Tru9I are similar.

Isolated from soil and human intestinal tracts.

The type strain is strain LMG 11157 (= DSM $3035=$ NRRL NRS-666). This strain has the characteristics of the species described above. However, the authenticity of the type strain in some culture collections may be in doubt. The type strain is positive for production of acid from inulin, L-fucose, and Dmelezitose and negative for casein hydrolysis and production of acid from gluconate.

FIG. 4. Normalized computer profiles from an SDS-PAGE analysis of whole-cell proteins of representatives of nine Paenibacillus species and of the related species $B$. peoriae, $B$. lautus and " $B$. longisporis." The dendrogram was based on UPGMA clustering of the correlation coefficients $(r)$ of the total protein profiles, with the zone to the left of arrow 4 excluded in order to obtain a homogeneous cluster of $P$. validus strains as described previously (14). Arrows 1 through 3 indicate other species-specific zones (to the left of the respective arrows) which were excluded from numerical analyses (data not shown) because of the presence of irregular dense high-molecular-weight bands as indicated in the text. 


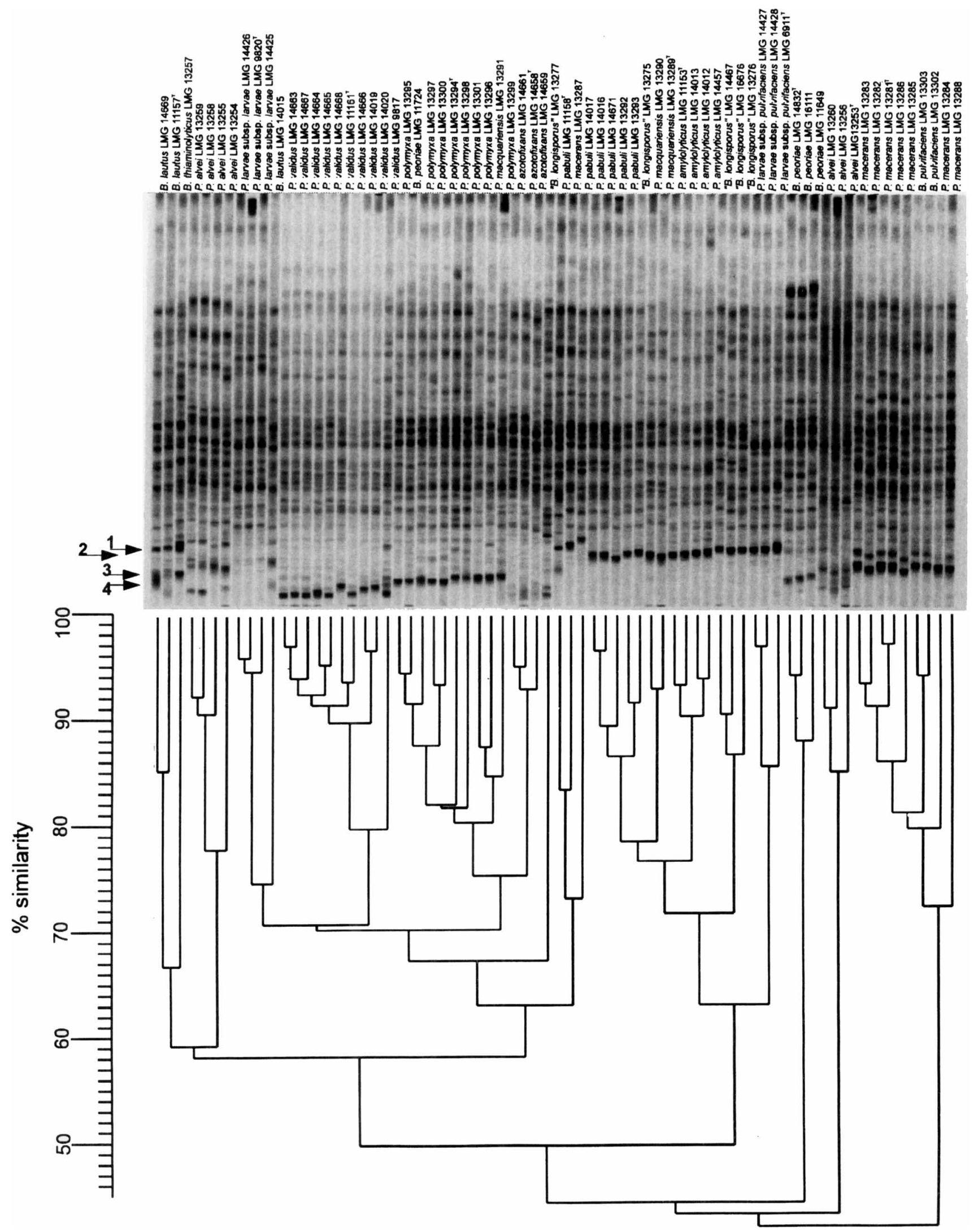




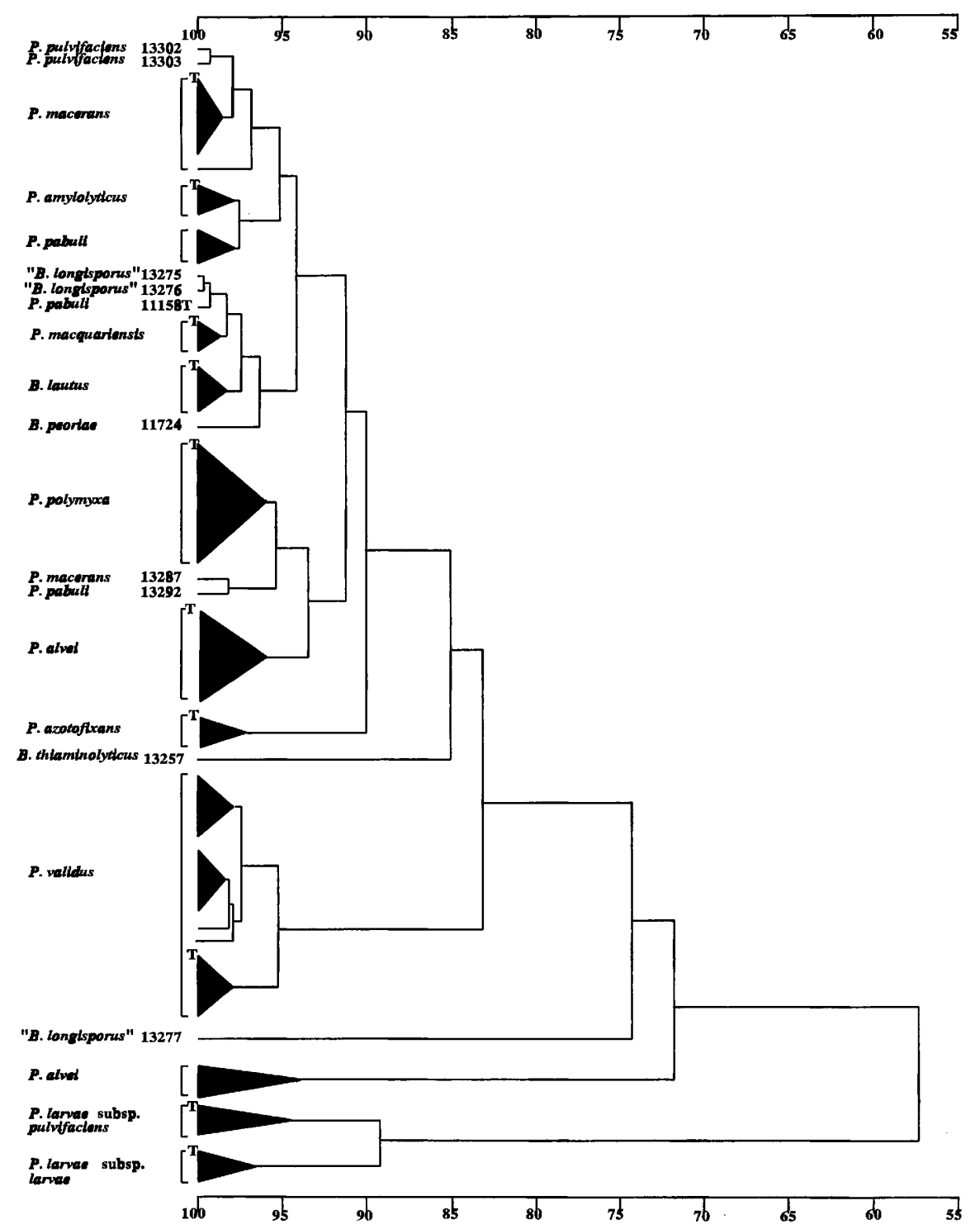

FIG. 5. Simplified dendrogram based on UPGMA clustering of similarity coefficients ( $S_{\mathrm{G}}$ values) of Py-MS data for representatives of nine Paenibacillus species and the related species B. peoriae, B. lautus, and "B. longisporus." $\mathrm{T}$ indicates the position of a type strain.

(viii) $\boldsymbol{P}$. macerans. In all of the analyses except the RAPD analysis (Fig. 6B), the $P$. macerans strains formed distinct clusters that were clearly separated from all other Paenibacillus species (Fig. 1 through 5 and 6A), and this species could be distinguished by using routine tests (Table 2).

There was, however, some evidence of appreciable betweenstrain variation. There was slight heterogeneity in the DpnII patterns in the ARDRA, which reflected the occurrence of some additional bands (Fig. 1B). The strains clustered quite loosely in the numerical analyses based on FAME data (with LMG 13288 being an outlier of clusters IIb and IIc in Fig. 2), API test data and other phenotypic observations (Fig. 3), SDSPAGE data (with LMG 13288 again being an outlier of the $P$. macerans cluster [Fig. 4]), and RAPD data obtained with the universal primer (Fig. 6A).

Two strains received from the Gibson collection as $B$. pulvifaciens (LMG 13302 and LMG 13303) were clearly misidentified, as they clustered with $P$. macerans in all of the analyses (Fig. 1 through 6). On the other hand, P. macerans LMG 13287 grouped with the type strain of $P$. pabuli in most of the analyses (see below).

(ix) $\boldsymbol{P}$. macquariensis. The psychrotrophic species $P$. macquariensis could be readily distinguished from other Paenibacillus species (Table 2). In the ARDRA (Fig. 1A), the numerical analysis of API test data and other phenotypic observations (Fig. 3), the Py-MS analysis (Fig. 5), and the RAPD analysis in which the universal primer was used (Fig. $6 \mathrm{~A})$, the $P$. macquariensis strains clustered together at high levels of similarity. In the ARDRA the $P$. macquariensis cluster was closely linked with " $B$. longisporus" LMG 13277 and formed part of a species group encompassing $P$. durum, $P$. amylolyticus, B. lautus, and $P$. azotofuxans (Fig. 1A), while in the analysis of data from API and other tests it joined a composite cluster containing $P$. amylolyticus, B. lautus, $P$. pabuli, and strains of "B. longisporus" (Fig. 3).

In some analyses between-strain variation was observed. On the FAME dendrogram, $P$. macquariensis $\mathrm{LMG} 13289^{\mathrm{T}}$ and LMG 13290 could not be separated (cluster Ic in Fig. 2), while 
$P$. macquariensis LMG 13291 clustered with the species group containing $P$. alvei and $P$. larvae subsp. pulvifaciens (cluster Ia in Fig. 2). Kämpfer (18) reported similar heterogeneity in the fatty acid profiles of $P$. macquariensis strains.

On the SDS-PAGE dendrogram (Fig. 4), P. macquariensis LMG $13289^{\mathrm{T}}$ and LMG 13290 were linked at a very high level of similarity, while $P$. macquariensis LMG 13291 was located in the $P$. polymyxa cluster. However, visual inspection of the protein patterns revealed that the overall profiles of the three strains were very similar, except for the position of a dense high-molecular-weight protein band. Indeed, when the zone containing this and other bands with molecular weights equal to or greater than $8.5 \times 10^{4}$ (indicated by arrow 2 in Fig. 4) were excluded, all three $P$. macquariensis strains clustered at a level of similarity of $93 \%$ and were clearly separated from the $P$. polymyxa cluster (data not shown). Finally, in the RAPD analysis performed with primer 42423 the $P$. macquariensis type strain joined the other two tightly clustered strains (LMG 13290 and LMG 13291) at a level of similarity of only $80 \%$ (Fig. 6B).

(x) P. pabuli. In all of the analyses in which it was included except the FAME analysis (Fig. 2), the type strain of $P$. pabuli behaved differently from most other $P$. pabuli strains. In the ARDRA (Fig. 1A), the analysis of API and other phenotypic test results (Fig. 3), and the SDS-PAGE analysis (Fig. 4), this strain clustered with the misidentified organism $P$. macerans LMG 13287, and in the last two analyses, it also clustered with $P$. pabuli LMG 14017 (although at a rather low level of similarity in the SDS-PAGE analysis). This anomalous behavior of the type strain was confirmed by investigating a new American Type Culture Collection subculture of the type strain (LMG 15970) by ARDRA; the two subcultures produced identical patterns and could be differentiated from the other $P$. pabuli strains on the basis of DpnII and BfaI patterns (Fig. 1B). Furthermore, the experimentally observed restriction fragments of the amplified 16S rDNA of the type strain matched very well the theoretically expected restriction fragments (data not shown) simulated by the DNASIS software on the basis of the 16S rRNA sequence (1) of the type strain obtained from the Ribosomal Database Project database (22a).

In the Py-MS analysis the type strain exhibited unexpectedly high levels of similarity to two "B. longisporus" strains (Fig. 5), while in all of the other analyses except the RAPD analysis the other $P$. pabuli strains were more similar to "B. longisporus" strains (Fig. 1A and 2 through 4). " $B$. longisporus" was described by Delaporte (7), but was not included on the Approved Lists of Bacterial Names (36) and so lost standing in bacterial nomenclature. In the RAPD analysis no reproducible bands were obtained for the $P$. pabuli type strain, and, especially when the universal primer was used, considerable between-strain variation was observed with the other $P$. pabuli strains (Fig. 6A).

In this polyphasic study we clearly demonstrated the genotypic and phenotypic heterogeneity of the present taxon $P$. pabuli, and the $P$. pabuli type strain occurred separate from the other $P$. pabuli strains in several analyses used. Nakamura (27) revived the name $B$. pabuli mainly on the basis of high levels of DNA homology among six strains, and four of these strains (LMG 11158 ${ }^{\mathrm{T}}$, LMG 14016, LMG 14017, and LMG 14671) were included in this study; however, our results suggest that the levels of DNA homology of the P. pabuli strains should be reexamined, along with strains of " $B$. longisporus."

(xi) B. peoriae. Dendrograms based on the results of API and other phenotypic tests and SDS-PAGE results (Fig. 3 and 4) confirmed the distinctness of the recently described species $B$. peoriae (25). The results of the ARDRA and API and other phenotypic tests (Fig. 1A and 3) also demonstrated the close phylogenetic and phenotypic relationship between this species and $P$. polymyxa. In the ARDRA these two species could be differentiated by only one or two bands in their DpnII restriction patterns (Fig. 1B), which was not sufficient for clear separation of the two species in the numerical analysis of the combined ARDRA patterns (Fig. 1A). Strain LMG 11724, which was received as $B$. polymyxa but was reclassified as $B$. peoriae by Montefusco et al. (25), behaved like a $P$. polymyxa strain in most of our analyses. On the FAME dendrogram the three $B$. peoriae strains studied were dispersed in clusters Ia, Ib, and Ic (Fig. 2), indicating that there was marked interstrain variability in the whole-cell fatty acids, which is consistent with the findings of Kämpfer (18) for Bacillus species. Strain LMG 11724 clustered in the species cluster containing $P$. polymyxa, $P$. macquariensis, $P$. pabuli, and "B. longisporus" (cluster Ic in Fig. 2 ), which confirmed the high level of relatedness between this strain and $P$. polymyxa indicated by the results of other analyses. It is evident that $B$. peoriae, which was not included in the phylogenetic analyses of Ash et al. $(1,2)$, should be reclassified as Paenibacillus peoriae comb. nov.

In the initial description of $B$. peoriae (25), which was based on the results of the traditional test methods of Gordon et al. (9), the organism was found to be citrate utilization positive and negative for acid production from glycerol, two characteristics which distinguish this species from $P$. polymyxa. In the present study the organisms were citrate negative and gave variable results for acid production from glycerol, but it must be appreciated that quite different test systems were used in the two studies. The emended description below is therefore based on our data and those of Montefusco et al. (25).

(xii) Emended description of Paenibacillus peoriae comb. nov. Paenibacillus peoriae (pe.o'.ri.ae L. gen. n. peoriae, of Peoria, named after Peoria, Ill., where the organism was studied). Motile, gram-positive rods with round ends that are 0.5 to $1.0 \mu \mathrm{m}$ wide by 3.0 to $6.0 \mu \mathrm{m}$ long and occur singly and in pairs and chains. Sporangia are regular and are swollen by subterminal ellipsoidal spores.

Facultatively anaerobic. Catalase positive.

The organism grows on routine media, such as nutrient agar, producing butyrous, thin, smooth, circular, translucent colonies that are about $2 \mathrm{~mm}$ in diameter after incubation for 2 to 3 days at $30^{\circ} \mathrm{C}$. The optimum growth temperature is 28 to $30^{\circ} \mathrm{C}$, the maximum temperature is 35 to $45^{\circ} \mathrm{C}$, and the minimum temperature is 5 to $10^{\circ} \mathrm{C}$.

As determined with API 20E strips, $o$-nitrophenyl- $\beta$-D-galactopyranoside and gelatin are hydrolyzed and the VogesProskauer reaction is positive, but arginine dihydrolase, hydrogen sulfide, urease, and indole are not produced and citrate is not utilized. Different strains give different results for nitrate reduction. Montefusco et al. (25) reported that all of their strains were positive for nitrate reduction.

In API 50CH galleries, when API CHB suspension medium is used, esculin is hydrolyzed, gas is produced from many carbohydrates, and acid is produced from the following compounds: amygdalin, arbutin, L-arabinose, D-cellobiose, D-fructose, galactose, gentiobiose, D-glucose, glycogen, lactose, maltose, D-mannose, mannitol, D-melibiose, methyl-D-mannoside, methylxyloside, D-raffinose, ribose, salicin, starch, sucrose, and D-xylose. Acid is not produced from adonitol, D-arabinose, D- and L-arabitol, dulcitol, erythritol, D- and L-fucose, inulin, 2-keto-D-gluconate, 5-keto-D-gluconate, D-lyxose, D-melezitose, meso-inositol, methyl-D-glucoside, sorbitol, L-sorbose, Dtagatose, D-trehalose, xylitol, and L-xylose. Different strains give different results with gluconate, glycerol, $N$-acetylglucosamine, rhamnose, and D-turanose. Montefusco et al. (25) 


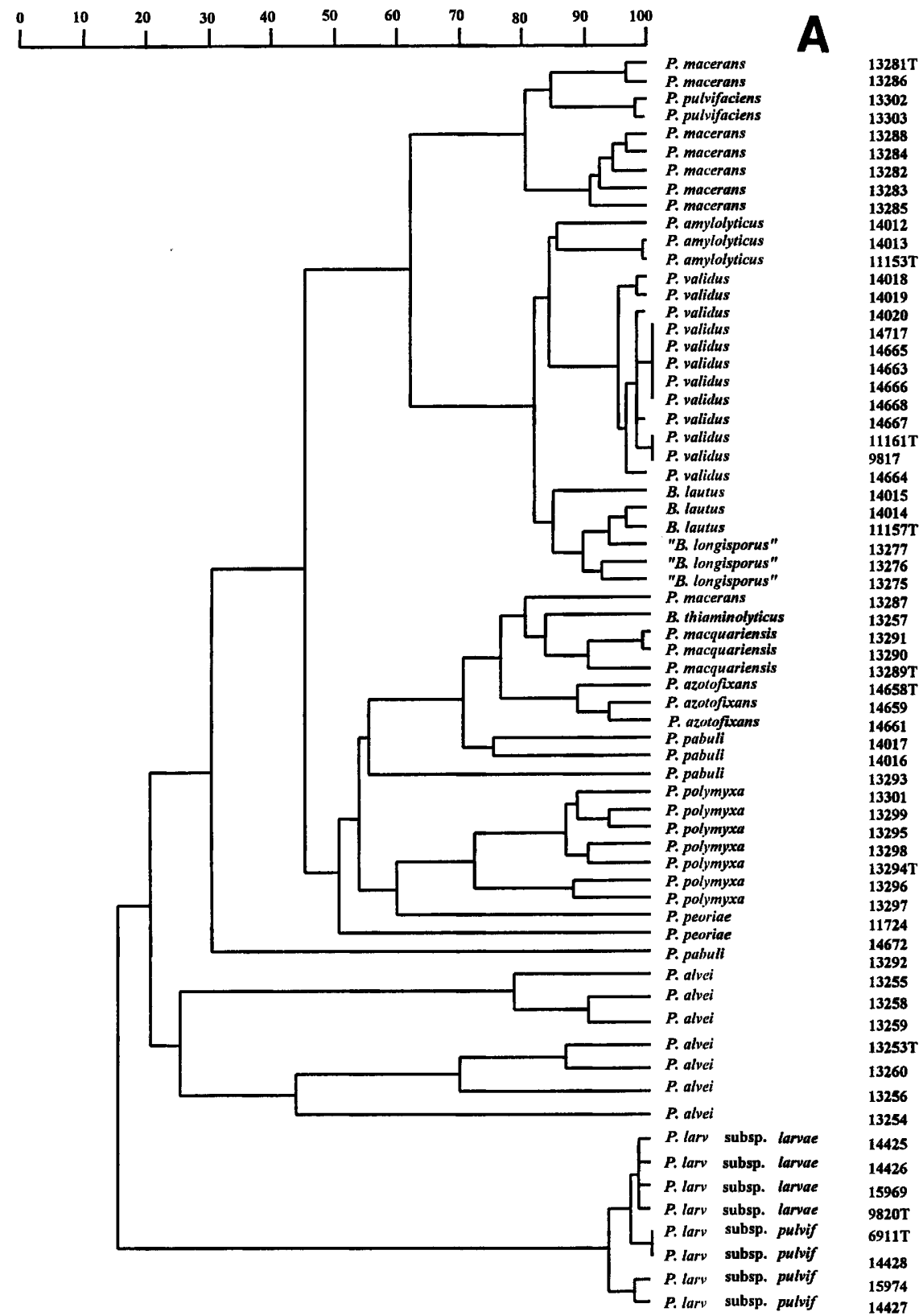

FIG. 6. Simplified dendrograms based on UPGMA clustering of correlation coefficients $(r)$ of RAPD patterns of representatives of nine Paenibacillus species and of the related species B. peoriae, B. lautus, and "B. longisporus" obtained with the universal primer (A) and primer 42423 (B). Abbreviations: $P$. larv subsp. larvae, $P$. larvae subsp. larvae; $P$. larv subsp. pulvif, $P$. larvae subsp. pulvifaciens.

reported that none of their strains produced acid from glycerol.

The following fatty acids are present and account for more than $1 \%$ of the total fatty acid content: $14: 0$ iso, 14:0, 15:0 iso, $15: 0$ anteiso, 16:0 iso, 16:1 $\omega 11 \mathrm{c}, 16: 0,17: 0$ iso, and 17:0 anteiso.

Casein is hydrolyzed by all strains, and growth is inhibited by $5 \% \mathrm{NaCl}$.

The average $\mathrm{G}+\mathrm{C}$ content is 45 to $47 \mathrm{~mol} \%$ as determined by the buoyant density method (25). The ARDRA patterns of the strains obtained with $H a e \mathrm{III}, D p n I I, R s a \mathrm{I}, B f a \mathrm{I}$, and Tru9I are similar.

Isolated mainly from soil and rotting vegetation.
The type strain is strain LMG 14832 (= NRRL B-14750). This strain has the characteristics of the species described above. The type strain is positive for production of acid from glycerol and $N$-acetylglucosamine and negative for nitrate reduction and production of acid from gluconate, rhamnose, and D-turanose.

(xiii) $\boldsymbol{P}$. polymyxa. The results of our analyses (Fig. 1 through 6 ) indicated that $P$. polymyxa is a distinct species, which nevertheless exhibited substantial genotypic heterogeneity in the ARDRA (e.g., the HaeIII pattern in Fig. 1B) and, especially when the universal primer was used, in the RAPD analysis (Fig. 6). Mavingui et al. (24) also observed substantial genetic diversity among their isolates when they were assayed by ri- 


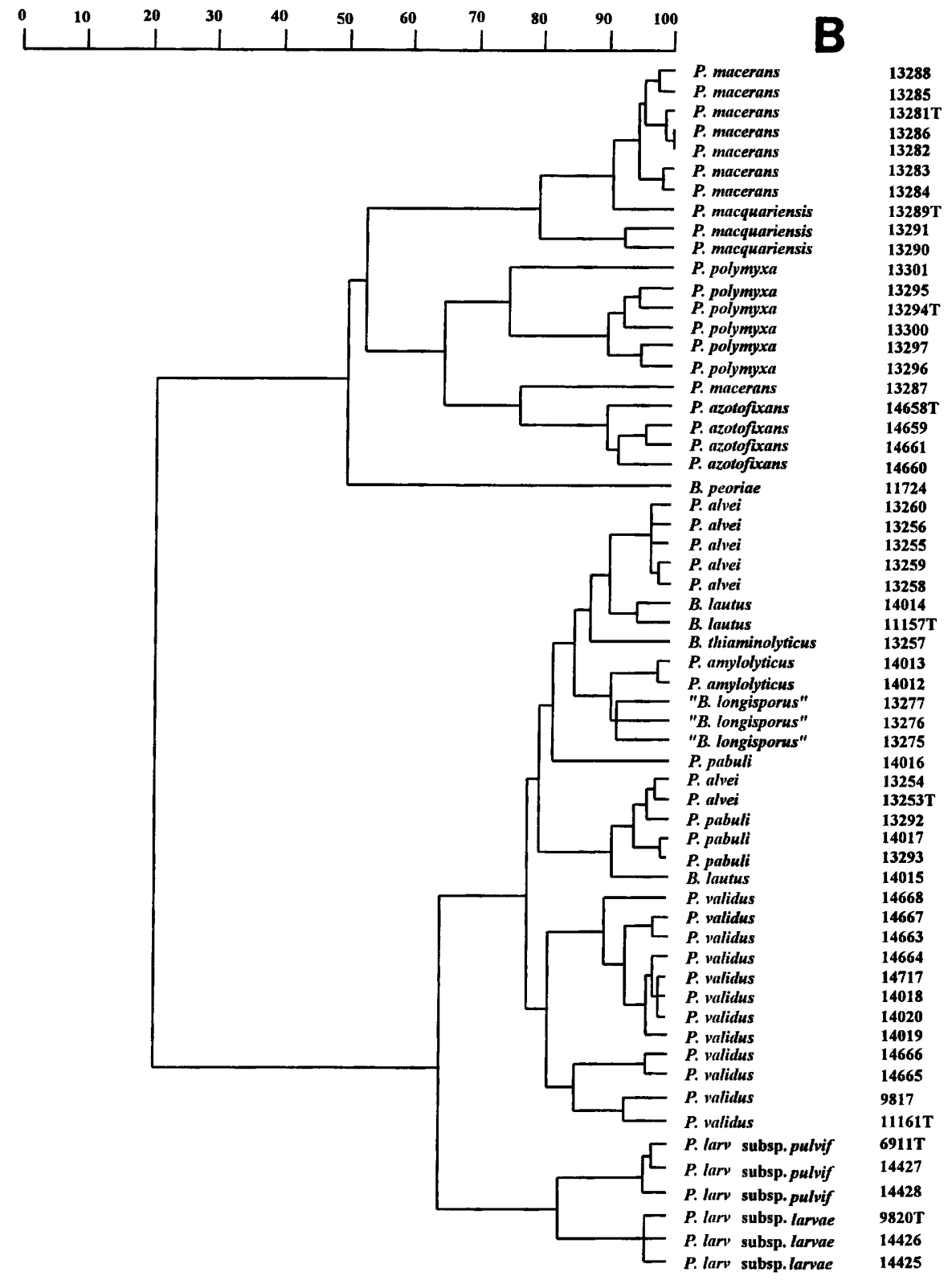

FIG. 6-Continued.

botyping with a $16 \mathrm{~S}$ rRNA probe. The $P$. polymyxa strains clustered together when numerical analyses of data from the FAME analysis, API and other phenotypic tests, SDS-PAGE, and Py-MS were performed (Fig. 2 through 5). As mentioned above, strain LMG 11724, which was received as $B$. polymyxa but was reclassified as $B$. peoriae by Montefusco et al. (25), behaved like a $P$. polymyxa strain in most of our analyses.

In the SDS-PAGE analysis the strains formed a loose cluster at a level of similarity of $80 \%$. This rather low value was mainly due to a dense and irregular high-molecular-weight band in the protein profiles, and when the zone containing this and all other bands with molecular weights equal to or greater than $9.8 \times 10^{4}$ (indicated by arrow 3 in Fig. 4) was excluded, all of the $P$. polymyxa strains clustered together at a level of similarity of $87 \%$ (data not shown). Within this cluster two groups with slightly different protein profiles were distinguished, and the division of clusters identified on the basis of the results of API and other phenotypic tests was similar in some respects to this arrangement. The possibility that there are $P$. polymyxa subspecies was suggested previously by Nakamura (28) on the basis of the results of DNA-DNA hybridization experiments, in which two subgroups with levels of DNA relatedness of 57 to $68 \%$ were distinguished. However, Nakamura felt that B. polymyxa could not be divided into subspecies because of a lack of reliable phenotypic characteristics; similarly, in our polyphasic study we found no definite characteristics that could be used to differentiate infraspecific groups. Although $P$. polymyxa is phenotypically closely related to $B$. peoriae, it can be distinguished by a small number of tests (Table 2 ).

(xiv) $\boldsymbol{P}$. validus. In a previous paper (14) we showed that $P$. gordonae is a later synonym of $P$. validus. The four $P$. validus and seven $P$. gordonae strains which we studied produced sim- 
ilar ARDRA patterns (Fig. 1A), clustered together (albeit quite loosely in most cases) on the basis of the results of the FAME analysis, API and other phenotypic tests, SDS-PAGE, Py-MS, and RAPD analysis (Fig. 2 through 6), and exhibited levels of DNA homology of more than $70 \%$ (14). The ARDRA data in the present study suggested that $P$. validus is phylogenetically related to $P$. polymyxa, $B$. peoriae, $P$. pabuli, and " $B$. longisporus" (Fig. 1A), which was consistent with the FAME data (cluster $\mathrm{Ib}$, which contained $P$. validus, and cluster Ic in Fig. 2).

\section{ACKNOWLEDGMENTS}

It is a pleasure to express our gratitude to L. K. Nakamura, F. Pichinoty, and L. Seldin for providing cultures.

P.D.V. and M.H. are indebted to the National Fund for Scientific Research (Belgium) for positions as a Senior Research Associate and a Postdoctoral Research Fellow, respectively, and N.A. is indebted to the University of Kuwait. R.C.W.B., M.H., N.A.L., and P.D.V. are most grateful to the British Council and the National Fund for Scientific Research (Belgium) for an Academic Research Collaboration Programme travel grant. K.K. acknowledges the Fund for Medical Scientific Research (Belgium) for personnel and research grants.

\section{REFERENCES}

1. Ash, C., J. A. E. Farrow, S. Wallbanks, and M. D. Collins. 1991. Phylogenetic heterogeneity of the genus Bacillus revealed by comparative analysis of small-subunit-ribosomal RNA sequences. Lett. Appl. Microbiol. 13:202-206.

2. Ash, C., F. G. Priest, and M. D. Collins. 1993. Molecular identification of rRNA group 3 bacilli (Ash, Farrow, Wallbanks and Collins) using a PCR probe test. Antonie van Leeuwenhoek 64:253-260.

3. Claus, D. and R. C. W. Berkeley, 1986. Genus Bacillus Cohn 1872, p. 1105-1139. In P. H. A. Sneath, N. S. Mair, M. E. Sharpe, and J. G. Holt (ed.), Bergey's manual of systematic bacteriology, vol. 2. The Williams \& Wilkins Co., Baltimore.

4. Clayton, R. A., G. Sutton, P. S. Hinkle, Jr., C. Bult, and C. Fields. 1995 Intraspecific variation in small-subunit rRNA sequences in GenBank: why single sequences may not adequately represent prokaryotic taxa. Int. J. Syst. Bacteriol. 45:595-599.

5. Collins, M. D., P. A. Lawson, A. Willems, J. J. Cordoba, J. FernandezGarayzabal, P. Garcia, J. Cai, H. Hippe, and J. A. E. Farrow. 1994. The phylogeny of the genus Clostridium: proposal of five new genera and eleven new species combinations. Int. J. Syst. Bacteriol. 44:812-826.

6. Costas, M. 1992. Classification, identification, and typing of bacteria by the analysis of their one-dimensional polyacrylamide gel electrophoretic protein patterns, p. 351-408. In A. Chambrach, M. J. Dunn, and B. J. Radola (ed.), Advances in electrophoresis, vol. 5. VCH Verlagsgesellschaft, Weinheim, Germany.

7. Delaporte, B. 1972. Trois nouvelles espèces de Bacillus: Bacillus similibadius n. sp., Bacillus longisporus n. sp. et Bacillus nitritollens n. sp. Ann. Inst. Pasteur (Paris) 123:821-834.

8. Goodacre, R., and R. C. W. Berkeley. 1990. Detection of small genotypic changes in Escherichia coli by pyrolysis mass spectrometry. FEMS Microbiol. Lett. 71:133-138.

9. Gordon, R. E., W. C. Haynes, and C. H.-N. Pang. 1973. The genus Bacillus. U.S. Dep. Agric. Agric. Handb. 427:1-283.

10. Gower, J. C. 1971. A general coefficient of similarity and some of its properties. Biometrics 27:857-874.

11. Gürtler, V., V. A. Wilson, and B. C. Mayall. 1991. Classification of medically important clostridia using restriction endonuclease site differences of PCRamplified 16S rDNA. J. Gen. Microbiol. 137:2673-2679.

12. Gutteridge, C. S., L. Vallis, and H. J. H. MacFie. 1985. Numerical methods in the classification of micro-organisms by pyrolysis mass spectrometry, $\mathrm{p}$. 369-401. In M. Goodfellow, D. Jones, and F. G. Priest (ed.), Computer assisted bacterial systematics. Academic Press, New York.

13. Heyndrickx, M., K. Vandemeulebroecke, B. Hoste, P. Janssen, K. Kersters, P. De Vos, N. A. Logan, N. Ali, and R. C. W. Berkeley. 1996. Reclassification of Paenibacillus (formerly Bacillus) pulvifaciens (Nakamura 1984) Ash et al. 1994, a later subjective synonym of Paenibacillus (formerly Bacillus) larvae (White 1906) Ash et al. 1994, as a subspecies of $P$. larvae. Emended description of $P$. larvae with $P$. larvae subsp. larvae and $P$. larvae subsp. pulvifaciens. Int. J. Syst. Bacteriol. 46:270-279.

14. Heyndrickx, M., K. Vandemeulehroecke, P. Scheldeman, B. Hoste, K. Kersters, P. De Vos, N. A. Logan, A. M. Aziz, N. Ali, and R. C. W. Berkeley. 1995. Paenibacillus (formerly Bacillus) gordonae (Pichinoty et al. 1986) Ash et al 1993 is a later subjective synonym of Paenibacillus (formerly Bacillus) validus (Nakamura 1984) Ash et al. 1993: emended description of $P$. validus. Int. J. Syst. Bacteriol. 45:661-669.
15. Heyndrickx, M., L. Vauterin, P. Vandamme, K. Kersters, and P. De Vos. Applicability of combined amplified $16 \mathrm{~S}$ rDNA restriction analysis (ARDRA) patterns in bacterial phylogeny and taxonomy. J. Microbiol. Methods, in press.

16. International Committee on Systematic Bacteriology. Subcommittee on the Taxonomy of the Genus Bacillus. 1993. Minutes of the meeting. Int. J. Syst. Bacteriol. 43:185.

17. Jurtshuk, R. J., C. Lin, P. Caneda, J. D. Wisoztsky, P. Jurtshuk, Jr., and G. E. Fox. 1989. 16S ribosomal RNA sequencing studies on organisms of the Bacillus species, abstr. R-10, p. 281. In Abstracts of the 89th Annual Meeting of the American Society for Microbiology 1989. American Society for Microbiology, Washington, D.C.

18. Kämpfer, P. 1994. Limits and possibilities of total fatty acid analysis for classification and identification of Bacillus species. Syst. Appl. Microbiol. 17:86-98.

19. Laguerre, G., M.-R. Allard, F. Revoy, and N. Amarger. 1994. Rapid identification of rhizobia by restriction fragment length polymorphism analysis of PCR-amplified 16S rRNA genes. Appl. Environ. Microbiol. 60:56-63.

20. Logan, N. A. 1994. Bacterial systematics. Blackwell Scientific Publications, Oxford.

21. Logan, N. A., and R. C. W. Berkeley. 1984. Identification of Bacillus strains using the API system. J. Gen. Microbiol. 130:1871-1882.

22. MacGowan, A. P., K. O'Donaghue, J. MacLaughlin, P. M. Bennet, and D. S. Reeves. 1993. Typing of Listeria spp. using random amplified polymorphic DNA (RAPD) analysis. J. Med. Microbiol. 38:322-327.

22a.Maidak, B. L., G. J. Olsen, N. Larsen, R. Overbeek, M. J. McCaughey, and C. R. Woese. 1996. The Ribosomal Database Project (RDP). Nucleic Acids Res. 24:82-85.

23. Marshall, B. J., and D. F. Ohye. 1966. Bacillus macquariensis n. sp., a psychrotrophic bacterium from sub-Antarctic soil. J. Gen. Microbiol. 44:4146.

24. Mavingui, P., G. Laguerre, O. Berge, and T. Heulin. 1992. Genetic and phenotypic diversity of Bacillus polymyxa in soil and in the wheat rhizosphere. Appl. Environ. Microbiol. 58:1894-1903.

25. Montefusco, A., L. K. Nakamura, and D. P. Labeda. 1993. Bacillus peoriae sp. nov. Int. J. Syst. Bacteriol. 43:388-390.

26. Murray, R. G. E., D. J. Brenner, R. R. Colwell, P. De Vos, M. Goodfellow, P. A. D. Grimont, N. Pfennig, E. Stackebrandt, and G. A. Zavarzin. 1990. Report of the Ad Hoc Committee on Approaches to Taxonomy within the Proteobacteria. Int. J. Syst. Bacteriol, 40:213-215.

27. Nakamura, L. K. 1984. Bacillus amylolyticus sp. nov., nom. rev., Bacillus lautus sp. nov., nom. rev., Bacillus pabuli sp. nov., nom. rev., and Bacillus validus sp. nov., nom. rev. Int. J. Syst. Bacteriol. 34:224-226.

28. Nakamura, L. K. 1987. Bacillus polymyxa (Prazmowski) Mace 1889 deoxyribonucleic acid relatedness and base composition. Int. J. Syst. Bacteriol. 37:391-397.

29. Nakamura, L. K. 1990. Bacillus thiaminolyticus sp. nov., nom. rev. Int. J. Syst. Bacteriol. 40:242-246.

30. Nesme, X., M. Vaneechoutte, S. Orso, B. Hoste, and J. Swings. 1995. Diversity and genetic relatedness within genera Xanthomonas and Stenotrophomonas using restriction endonuclease site differences of PCR-amplified $16 \mathrm{~S}$ rRNA gene. Syst. Appl. Microbiol. 18:127-135.

31. Norris, J. R., R. C. W. Berkeley, N. A. Logan, and A. G. O'Donnell. 1981. The genera Bacillus and Sporolactobacillus, p. 1711-1742. In M. P. Starr, H. Stolp, H. G. Trüper, A. Balows, and H. G. Schlegel (ed.), The prokaryotes. Springer-Verlag, Berlin.

32. Pichinoty, F., J. B. Waterbury, M. Mandel, and J. Asselineau. 1986. Bacillus gordonae sp. nov., une nouvelle espèce appartenant au second groupe morphologique, dégradant divers composés aromatiques. Ann. Inst. Pasteur/ Microbiol (Paris) 137A:65-78.

32a.Pitcher, D. G., N. A. Saunders, and R. J. Owen. 1989. Rapid extraction of bacterial genomic DNA with guanidium thiocyanate. Lett. Appl. Microbiol. 8:151-156.

33. Pot, B., P. Vandamme, and K. Kersters. 1994. Analysis of electrophoretic whole organism protein fingerprints, p. 493-521. In M. Goodfellow and A. G. O'Donnell (ed.), Chemical methods in prokaryotic systematics. J. Wiley \& Sons, Chichester, United Kingdom.

34. Rössler, D., W. Ludwig, K.-H. Schleifer, C. Lin, T. J. McGill, J. D. Wisoztsky, P. Jurtshuk, Jr., and G. E. Fox. 1991. Phylogenetic diversity in the genus Bacillus as seen by $16 \mathrm{~S}$ rRNA sequencing studies. Syst. Appl. Microbiol. 14:266-269.

35. Seldin, L., J. D. Van Elsas, and E. G. C. Penido. 1984. Bacillus azotofixans sp. nov., a nitrogen-fixing species from Brazilian soils and grass roots. Int. J. Syst. Bacteriol. 34:451-456.

36. Skerman, V. B. D., V. McGowan, and P. H. A. Sneath (ed.). 1980. Approved lists of bacterial names. Int. J. Syst. Bacteriol. 30:225-420.

37. Slepecky, R. A., and H. E. Hemphill. 1991. The genus Bacillus-nonmedical, p. 1663-1696. In A. Balows, H. G. Trüper, M. Dworkin, W. Harder, and K.-H. Schleifer (ed.), The prokaryotes. Springer-Verlag, New York.

38. Smith, N. R., R. E. Gordon, and F. E. Clark. 1946. Aerobic mesophilic sporeforming bacteria. USDA miscellaneous publication no. 559. U.S. Department of Agriculture, Washington, D.C. 
39. Smith, N. R., R. E. Gordon, and F. E. Clark. 1952. Aerobic sporeforming bacteria. U.S. Department of Agriculture Monograph no. 16. U.S. Department of Agriculture. Washington, D.C.

40. Van Belkum, A. 1994. DNA fingerprinting of medically important microorganisms by use of PCR. Clin. Microbiol. Rev. 7:174-184.

41. Vandamme, P., B. Pot, M. Gillis, P. De Vos, K. Kersters, and J. Swings. 1996. Polyphasic taxonomy, a consensus approach to bacterial systematics. Microbiol. Rev. 60:407-438.

42. Vauterin, L., and P. Vauterin. 1992. Computer aided objective comparison of electrophoretic patterns for grouping and identification of microorganisms. Eur. Microbiol. 1:37-41.

43. Vauterin, L., P. Yang, B. Hoste, M. Vancanneyt, E. L. Civerolo, J. Swings, and K. Kersters. 1991. Differentiation of Xanthomonas campestris pv. citri strains by sodium dodecyl sulfate-polyacrylamide gel electrophoresis of pro- teins, fatty acid analysis, and DNA-DNA hybridization. Int. J. Syst. Bacteriol. 41:535-542.

44. Wayne, L. G., D. J. Brenner, R. R. Colwell, P. A. D. Grimont, O. Kandler, M. I. Krichevsky, L. H. Moore, W. E. C. Moore, R. G. E. Murray, E. Stackebrandt, M. P. Starr, and H. G. Trüper. 1987. Report of the Ad Hoc Committee on Reconciliation of Approaches to Bacterial Systematics. Int. J. Syst. Bacteriol. 37:463-464.

45. Welch, D. F. 1991. Applications of cellular fatty acid analysis. Clin. Microbiol. Rev. 4:422-438.

46. Wilson, M. J., W. G. Wade, and A. J. Weightman. 1995. Restriction fragment length polymorphism analysis of PCR-amplified 16S ribosomal DNA of human Capnocytophaga. J. Appl. Bacteriol. 78:394-401.

47. Woese, C. 1987. Bacterial evolution. Microbiol. Rev. 51:221-271. 